\title{
Final Report of the Decontamination and Decommissioning of the BORAX-V Facility Turbine Building
}

\author{
Alvin E. Arave \\ Glenn R. Rodman \\ Published December 1992 \\ Idaho National Engineering Laboratory \\ EG\&G Idaho, Inc. \\ Idaho Falls, Idaho 83415
}




\begin{abstract}
The Boiling Water Reactor Experiment (BORAX)-V Facility Turbine Building Decontamination and Decommissioning (D\&D) Project is described in this report. The BORAX st ies of five National Reactor Testing Station (NRTS) reactors pioneered intensive work on boiling water reactor (BWR) experiments conducted between 1953 and 1964. Facility characterization, decision analyses, and D\&D plans for the turbine building were prepared from 1979 through 1990. D\&D activities of the turbine building systems were initiated in November of 1988 and completed with the demolition and backfill of the concrete foundation in March 1992. Due to the low levels of radioactivity and the absence of loose contamination, the D\&D activities were completed with no radiation exposure to the workers. The D\&D activities were performed in a manner that no radiological health or safety hazard to the public or to personnel at the Idaho National Engineering Laboratory (INEL) remain.
\end{abstract}




\section{SUMMARY}

This final report is a description of the Boiling Water Reactor Experiment (BORAX)-V Facility Turbine Building decontamination and decommissioning (D\&D) activities. The BORAX-V facility is located in the southwestern portion of the Idaho National Engineering Laboratory (INEL) approximately $3 / 4$ mile north of the Experimental Breeder Reactor I (EBR-I) facility. The BORAX series of reactor experiments were conducted between 1953 and 1964 . This series of experiments began in 1953 with BORAX-I which was used to demonstrate the feasibility of boiling water reactors (BWRs) and was deliberately destroyed in 1954 to determine its inherent safety under extreme conditions. BORAX-II was constructed on a new site, northeast of BORAX-I, in late 1954 for further tests. BORAX-III was designed to investigate the use of BWRs for generating electric power and on July 17, 1955, produced sufficient electricity to power and light the city of Arco, Idaho- an American first. BORAX-IV operated from 1956-1958, and was used to test high-thermal-capacity fuel elements.

BORAX-V was used for determining the safety aspects and feasibility of an integral nuclear superheat system from 1962-1964. The BORAX-II,-III,-IV, and - V experiments were housed in two main buildings, the reactor building (AEF-601) and the turbine building (AEF-602), later redesignated as Buildings Nos. 717 and 718 , respectively.

Radiological characterization of the reactor and turbine building systems was originally performed in May of 1979. Dismantlement was selected as the preferred decommissioning alternative in 1979 and a D\&D Plan for the BORAX-V facility was prepared proposing that the turbine building be removed from the facility site. However, because a rigorous approach was not taken in selecting dismantlement as the preferred D\&D alternative, other alternatives were considered in a subsequent decision analysis prepared in 1984. Five altematives for D\&D of the BORAX-V facility were considered and compared based on estimated cost, material reuse, facility reuse, surveillance and maintenance costs, volume of waste generated, hazards to D\&D workers, short-term impact on INEL personnel and operations, and long-term impact to the public. The recommended alternative was to stabilize the reactor building systems in place and perform total dismantlement of the remainder of the facility which was consistent with the original D\&D Plan. The BORAX-V facility was designated for decommissioning in 1985 and the D\&D Plan was revised in April of 1985 to reflect the results of the decision analysis. The planned scope of the D\&D work for the turbine building was to remove all systems and equipment from the building, move or dismantle the metal building, decontaminate the concrete foundation to acceptable release limits, and demolish the concrete foundation to $6 \mathrm{ft}$ below grade. The turbine building area would be backfilled, covered with top soil, and reseeded with native grasses. An additional decision analysis was prepared in December 1988 considering the current condition of the facility and to address the environmental issues as of October 1988. The recommended alternative of this decision analysis was consistent with the alternative selected in 1985. Total dismantlement of the BORAX-V facility was reconsidered by Department of Energy Idaho Field Office (DOE-ID) and EG\&G Idaho in the spring of 1989. DOE-ID decided on total dismantlement as the preferred D\&D alternative and documented this decision by letter to EG\&G Idaho, in June 1989.

Additional radiological characterization of known or suspected contaminated systems and equipment located inside the turbine building was performed in May of 1989 to provide data for waste disposal at the Radioactive Waste Management Complex (RWMC), property management excess yard, and sanitary landfill. Low levels of contamination were found inside systems that were interconnected with the reactor building systems. No loose contamination was detected in the turbine building. Sampling was also performed in the turbine building in the spring of 1989 to identify any hazardous or mixed waste. 
The results of this characterization verified the absence of hazardous chemical compounds which allowed compliance with low-level radioactive waste acceptance and sanitary landfill criteria of the INEL.

Major turbine building D\&D activities started in 1988 and were completed with demolition and backfill of the building foundation in 1992 after receipt of the verification statement from the Independent Verification Contractor (IVC). The turbine building and immediate area conforms to the guideline outlined in the Verification and Certification Protocol for the Formerly Utilized Sites and Surplus Facilities Management Programs (DOE, November, 1990). Covering the area with top soil and reseeding with native grasses will be accomplished concurrently with the reactor building area upon completion of its D\&D activities.

Cost-saving techniques were applied to some of the D\&D activities. A mobile 60-ton crane was obtained from Property Management excess yard and put back into service for use at BORAX-V and other D\&D projects. Decontamination of the contaminated concrete in the turbine building basement was accomplished by removal of small areas of the sump pit and trench rather than removal of the entire trench. A removable access control fence was attached directly to the turbine building foundation rather than erecting a fence around the perimeter of the building.

The total cost of decommissioning the BORAX-V turbine building was approximately $\$ 1.5 \mathrm{M}$. The radiological contaminated waste generated was $2,485 \mathrm{ft}^{3}$ of carbon steel, $139 \mathrm{ft}^{3}$ of concrete, $386 \mathrm{ft}^{3}$ of asbestos and asbestos covered piping, $38 \mathrm{ft}^{3}$ of soil, $192 \mathrm{ft}^{3}$ of wood, $192 \mathrm{ft}^{3}$ of incinerable and $48 \mathrm{ft}^{3}$ of compactible personal protective equipment (PPE). Uncontaminated waste generated was $11,520 \mathrm{ft}^{3}$ of concrete (buried in place), and $1,184 \mathrm{ft}^{3}$ of carbon steel. In addition, $21 \mathrm{ft}^{3}$ of hazardous waste was generated. D\&D workers did not receive any radiation exposure above background levels. 


\section{ACKNOWLEDGMENTS}

The Decontamination and Decommissioning (D\&D) of the BORAX-V Facility Turbine Building was a culmination of efforts of many individuals. Special recognition is given to Robert W. Tyng, who served as work package planner and site supervisor for the D\&D work described in this report. Appreciation is extended to the EG\&G Idaho Program Support Group personnel who performed the scheduling and D\&D activities. 


\section{CONTENTS}

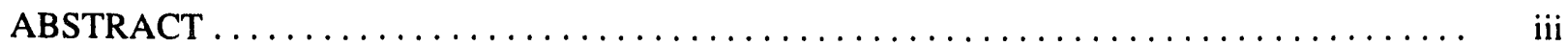

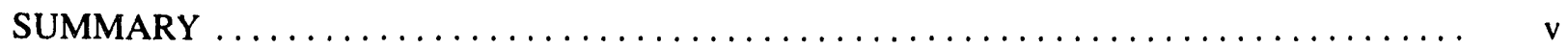

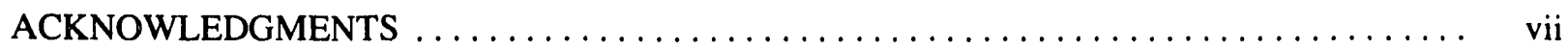

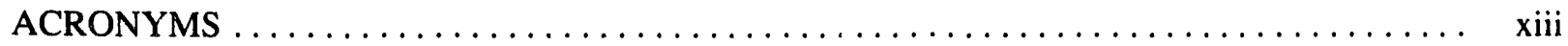

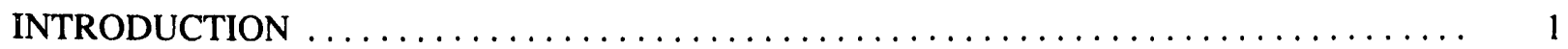

BORAX-V History $\ldots \ldots \ldots \ldots \ldots \ldots \ldots \ldots \ldots \ldots \ldots \ldots \ldots \ldots \ldots \ldots \ldots \ldots, 1$

BORAX-V Decommissioning Project Background $\ldots \ldots \ldots \ldots \ldots \ldots \ldots \ldots \ldots, 2$

BORAX-V FACILITY DESCRIPTION PRIOR TO DECOMMISSIONING $\ldots \ldots \ldots \ldots \ldots \ldots$

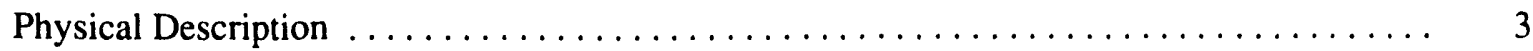

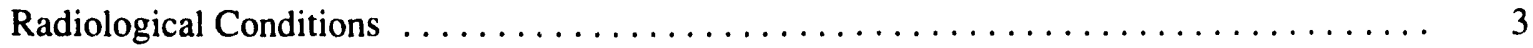

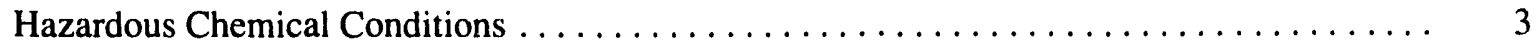

DECOMMISSIONING OBJECTIVES AND WORK SCOPE $\ldots \ldots \ldots \ldots \ldots \ldots \ldots \ldots \ldots, 14$

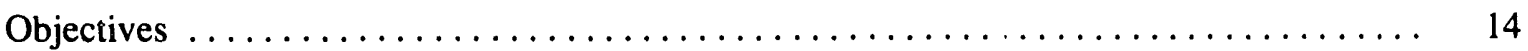

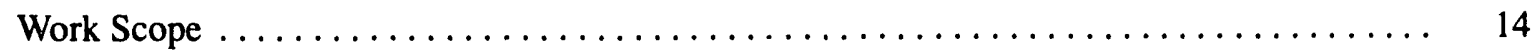

WORK PERFORMED $\ldots \ldots \ldots \ldots \ldots \ldots \ldots \ldots \ldots \ldots \ldots \ldots \ldots \ldots \ldots \ldots \ldots, 15$

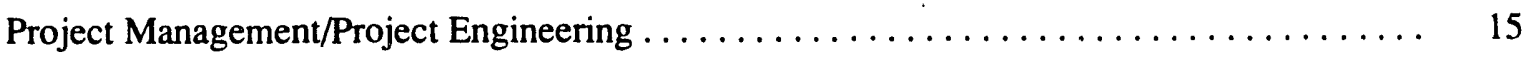

Decision Analysis . . . . . . . . . . . . . . . . . . . . . . . . . . . . . . 15

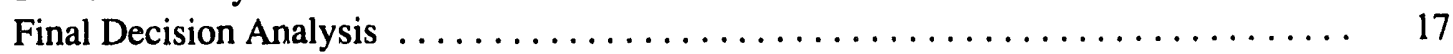

D\&D Plan and Work Packages $\ldots \ldots \ldots \ldots \ldots \ldots \ldots \ldots \ldots \ldots \ldots \ldots \ldots \ldots \ldots \ldots, 17$

Site Preparation $\ldots \ldots \ldots \ldots \ldots \ldots \ldots \ldots \ldots \ldots \ldots \ldots \ldots \ldots \ldots \ldots \ldots \ldots \ldots \ldots \ldots, 18$

Decommissioning Operations and Waste Disposal $\ldots \ldots \ldots \ldots \ldots \ldots \ldots \ldots \ldots \ldots, 18$

Post-Decommissioning Radiological Survey $\ldots \ldots \ldots \ldots \ldots \ldots \ldots \ldots \ldots \ldots \ldots, 32$

Post-Decommissioning Hazardous Chemical Surveys $\ldots \ldots \ldots \ldots \ldots \ldots \ldots \ldots \ldots, 36$

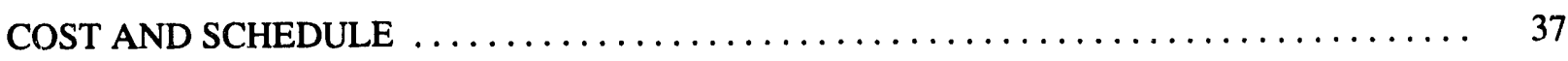

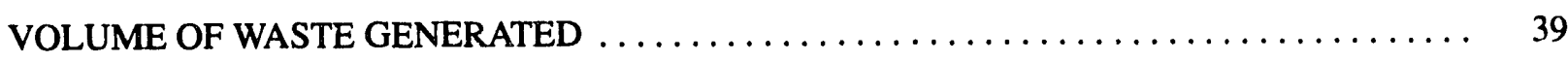

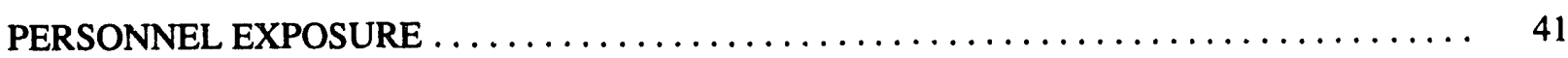




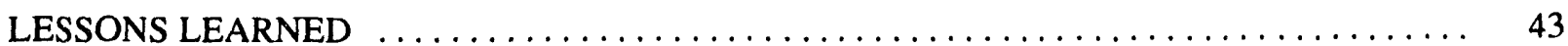

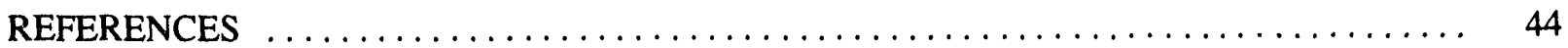

\section{FIGURES}

1. Location of BORAX-V facility within the INEL $\ldots \ldots \ldots \ldots \ldots \ldots \ldots \ldots \ldots \ldots$

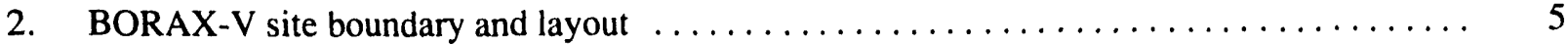

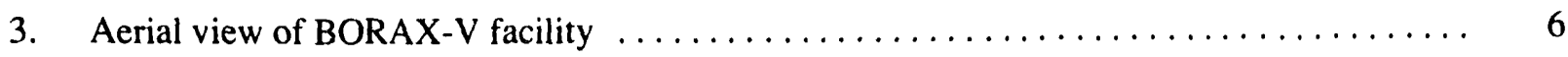

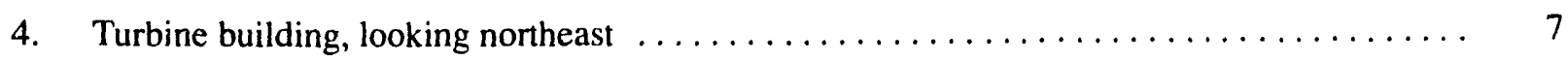

5. Turbine building equipment layout $\ldots \ldots \ldots \ldots \ldots \ldots \ldots \ldots \ldots \ldots \ldots \ldots \ldots \ldots \ldots \ldots \ldots$

6. View of 1926 Westinghouse turbine-generator $\ldots \ldots \ldots \ldots \ldots \ldots \ldots \ldots \ldots \ldots$

7. View of turbine building main floor $\ldots \ldots \ldots \ldots \ldots \ldots \ldots \ldots \ldots \ldots \ldots \ldots$

8. View of equipment in turbine building basement, looking south $\ldots \ldots \ldots \ldots \ldots \ldots \ldots \ldots$

9. View of equipment in turbine building basement, looking north $\ldots \ldots \ldots \ldots \ldots \ldots \ldots \ldots$

10. Work breakdown structure for BORAX-V turbine building D\&D project $\ldots \ldots \ldots \ldots \ldots \ldots$

11. Disassembly of steam turbine assembly $\ldots \ldots \ldots \ldots \ldots \ldots \ldots \ldots \ldots \ldots \ldots \ldots$

12. Removal of the steam turbine upper casing from the turbine building $\ldots \ldots \ldots \ldots \ldots \ldots$

13. Preparing the steam turbine upper casing for shipment to RWMC $\ldots \ldots \ldots \ldots \ldots \ldots \ldots 21$

14. Removal of the pink tank from turbine building $\ldots \ldots \ldots \ldots \ldots \ldots \ldots \ldots \ldots \ldots \ldots \ldots \ldots \ldots$

15. Disassembly of the 10 -ton maintenance rail crane $\ldots \ldots \ldots \ldots \ldots \ldots \ldots \ldots \ldots \ldots \ldots \ldots \ldots \ldots \ldots$

16. View of a portion of the radiologically clean equipment removed from turbine

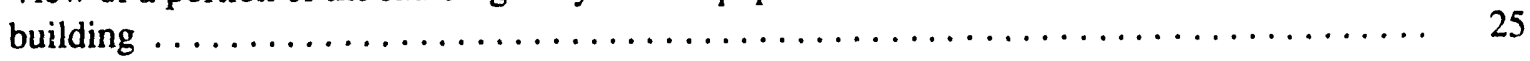

17. Preparation for removal of the gland seal water tank $\ldots \ldots \ldots \ldots \ldots \ldots \ldots \ldots \ldots$

18. Removal of the generator rotor from the stator $\ldots \ldots \ldots \ldots \ldots \ldots \ldots \ldots \ldots \ldots \ldots$

19. Preparation of the generator stator for shipment to $\mathrm{RWMC} \ldots \ldots \ldots \ldots \ldots \ldots \ldots \ldots$

20. Removal of the upper section of the condenser vessel from turbine building $\ldots \ldots \ldots \ldots \ldots 28$

21. Removal of the 15 -ton condenser vessel from turbine building $\ldots \ldots \ldots \ldots \ldots \ldots \ldots \ldots$

22. Removal of a section of the turbine-generator steel support structure from the turbine

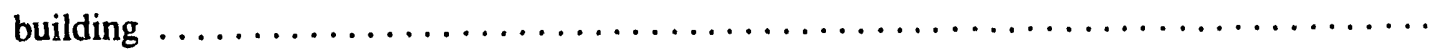


23. Removal of a portion of turbine building metal framework $\ldots \ldots \ldots \ldots \ldots \ldots \ldots \ldots$

24. Removal of a portion of the turbine building roof $\ldots \ldots \ldots \ldots \ldots \ldots \ldots \ldots \ldots$

25. View of turbine building foundation prior to demolition and backfill activities $\ldots \ldots \ldots$

26. View of turbine building basement prior to demolition and backfill activities $\ldots \ldots \ldots \ldots$

27. View of demolition of turbine building east wall $\ldots \ldots \ldots \ldots \ldots \ldots \ldots \ldots \ldots \ldots \ldots$

28. View of demolition of turbine building west wall $\ldots \ldots \ldots \ldots \ldots \ldots \ldots \ldots \ldots \ldots$

29. View of turbine building foundation after demolition of east, west, and south walls $\ldots \ldots \ldots 34$

30. View of bulldozer completing breakup of turbine building main floor concrete $\ldots \ldots \ldots \ldots$

31. View of remaining pieces of concrete foundation prior to completion of backfilling

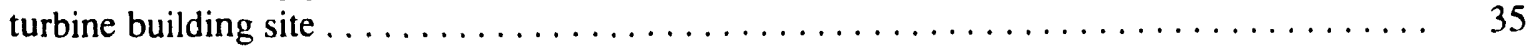

32. View of turbine building site at completion of backfilling and contouring $\ldots \ldots \ldots \ldots \ldots$

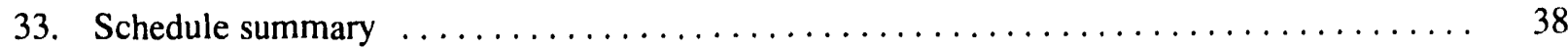

\section{TABLES}

1. Results of May 1979 radiological survey of systems at the turbine building $\ldots \ldots \ldots \ldots \ldots 12$

2. Results of May 1989 radiological survey at the turbine building $\ldots \ldots \ldots \ldots \ldots \ldots \ldots \ldots$

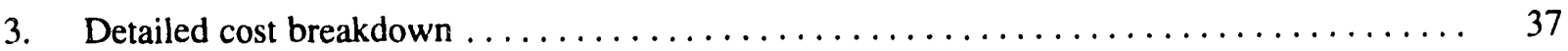

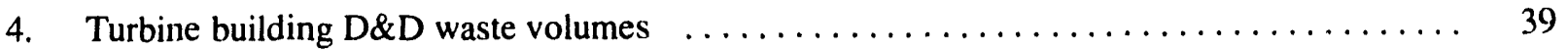




\section{ACRONYMiS}

ACM

$\begin{array}{ll}\text { ALARA } & \text { as low as reasonably achievable } \\ \text { BORAX } & \begin{array}{l}\text { Boiling Water Reactor } \\ \text { Experiment }\end{array}\end{array}$

BWR boiling water reactor

CFA Central Facilities Area

D\&D decontamination and decommissioning

$\begin{array}{ll}\text { DOE-HQ } & \begin{array}{l}\text { Department of Energy } \\ \text { Headquarters }\end{array}\end{array}$

DOE-ID Department of Energy' Idaho Field Office

EBR-I Experimental Breeder Reactor I

EC Environmental Checklist

EG\&G Idaho EG\&G Idaho, Inc.

ERP Environmental Restoration

Program

GM Geiger/Mueller

HP health physics (technician)

HWSF Hazardous Waste Storage Facility

IH industrial hygienist

INEL Idaho National Engineering Laboratory
IVC

MTF

NEPA

NRTS

ORNL-GJ

PAG

PCB

PPE

RAC

RCRA

RML

RWMC

SWR

TLD

UST

WBS

WERF
Independent Verification Contractor

memorandum-to-file

National Environmental Policy

Act

National Reactor Testing Station

Oak Ridge National

Laboratory-

Grand Junction

Pollutant Assessments Group

polychlorinated biphenyl

personal protective equipment

Remedial Action Contracts

Resource Conservation and Recovery Act

Radiation Measurements Laboratory

Radioactive Waste Management Complex

Site Work Release

thermoluminescent dosimeter

underground storage tank

Work Breakdown Structure

Waste Experimental Reduction Facility 


\section{Final Report of the Decontamination and Decommissioning of the BORAX-V Facility Turbine Building}

\section{INTRODUCTION}

This final report describes the tasks performed by the EG\&G Idaho, Inc. (EG\&G Idaho) Environmental Restoration Decontamination and Decommissioning (D\&D) Program to accomplish D\&D of the Boiling Water Reactor Experiment (BORAX)-V Facility Turbine Building at the Idaho National Engineering Laboratory (INEL). The report also summarizes the cost and duration of the project, radiation exposure to personnel, and the waste volume generated.

\section{BORAX-V History}

The BORAX facility was constructed during the 1950s on the National Reactor Testing Station (NRTS) for boiling water reactor (BWR) experiments near the Experimental Breeder Reactor (EBR) I site on the southwest end of the testing station. The BORAX reactor experiments 1,2 were conducted from 1953 through 1964 and included the following:

- BORAX-I, an open-top boiling water reactor was the first in a series of five NRTS reactors which pioneered intensive work on BWRs. BORAX-I was deliberately destroyed in July 1954 to determine its inherent safety under extreme operating conditions. The BORAX-I reactor site was cleaned up and then buried in place.

- BORAX-II was constructed a short distance northeast of BORAX-I in late 1954 for further tests and new core combinations using varying enrichments of uranium-235 in metal fuel plates. The power level of the BORAX-II reactor was six megawatts (MW, thermal).

- BORAY.-III, operated in 1955, was designed for a power level of $15 \mathrm{MW}$ (thermal), compared with the 1.4 MW (ther- mal) level of BORAX-I, and used a 2,000-kilowatt ( $\mathrm{kWe}$, electrical) turbine generator to investigate use of BWRs for generating electric power. On July 17 , 1955, BORAX-III gained historical significance as the first nuclear reactor to supply electricity to a city, Arco, Idaho-an American first. During the period of about two hours, BORAX-III generated approximately $2,000 \mathrm{kWe}$ distributed as follows: $500 \mathrm{kWe}$ to light Arco, $500 \mathrm{kWe}$ to power the BORAX facility, and $1,000 \mathrm{kWe}$ to power the Central Facilities Area (CFA) at NRTS. The vessel housed high-thermal-capacity fuel elements made from mixed oxides of uranium and thorium.

- BORAX-IV, $20 \mathrm{MW}$ (thermal), operated from December 1956 through June 1958. This reactor was used principally to test high-thermal-capacity fuel elements made from mixed oxides (ceramics) of uranium and thorium. The ceramic core of uraniumthorium oxide fuel elements demonstrated the feasibility of stable operation with this fuel which could be operated at higher temperatures, was less reactive with water coolant in case of cladding rupture, was cheaper to manufacture, and had higher burnup possibilities. BORAX-IV was also operated satisfactorily with several experimentally defective fuel elements in the core which resulted in only minor contamination of auxiliary equipment. An entombment of this vessel in place, using sand capped with concrete, isolated radioactive exposure of personnel during follow-on BORAX-V experiments. BORAX-II, -III, and -IV experiments were conducted on the same site as the existing BORAX-V facility using much the same equipment. 
- BORAX-V, with a design power of $40 \mathrm{MW}$ (thermal), provided a facility that was very flexible for determining the safety aspect and feasibility of an integral nuclear superheat system. BORAX-V produced superheated (dry) steam wholly by nuclear means for the first time on October 19, 1963. A flexible primary coolant system design allowed experiments using three separate BWR core configurations: a centrally located superheater, a peripherally located superheater, and a core without a superheater. All configurations allowed operation with natural or forced circulation of water through the core. A final BORAX-V experiment demonstrated the negligible contamination to turbo-generator equipment which resulted from operating with an experimentally defective fuel element in the superheater core. The reactor was placed on standby status in September 1964.

\section{BORAX-V Decommissioning Project Background}

The U. S. Department of Energy Idaho Field Office (DOE-ID), has assigned EG\&G Idaho the responsibility for implementing the D\&D Program at the INEL.

The BORAX-V facility was originally radiologically characterized in May 1979. A D\&D Plan $^{3}$ was prepared in 1979 for the facility proposing that the turbine building equipment be removed and the structure be dismantled or moved to another location for reuse. A decision analysis ${ }^{4}$ was prepared in 1984 to consider other D\&D alternatives. The recommended alternative was total dismantlement of the turbine building. Revision $1^{5}$ to the D\&D Plan was written and issued in April 1985 which was based on entombment of the reactor building systems located below the main floor level. Revision $2^{6}$ to the D\&D Plan was released in November 1988 reflecting the limited activities performed between 1985 and 1988. A second decision analysis ${ }^{7}$ was issued in December 1988 considering the condition of the facility on October 1, 1988 and to address current environmental issues. Revision $3^{8}$ to the D\&D Plan was issued in September 1990 to incorporate the decision made in June 1989 for total dismantlement of the BORAX-V facility and an approach which divided the D\&D of the turbine and reactor buildings into two phases. 


\section{BORAX-V FACILITY DESCRIPTION PRIOR TO DECOMMISSIONING}

\section{Physical Description}

The BORAX-V Reactor Facility is located in the southwestern portion of the INEL near the EBR-I Reactor Facility as shown in Figure 1. Figure 2 shows the BORAX-V facility site boundary and layout. The aerial view shown in Figure 3 shows the remaining structures as of 1987 which consisted of the turbine building, the reactor building foundation covered by a temporary cover, the electrical substation, and three small concrete pads whose buildings were previously removed. Figure 4 is an exterior view of the $40 \times$ 60 -ft-long Butler steei turbine building. The turbine building had 17 -ft high walls which supported 24-ft gables. Two personnel doors and an equipment door provided access to the building. The foundation was made from standard steelreinforced concrete with a heavy steel structure bolted to the supports on the basement floor to support the turbine-generator unit. At the time of decommissioning, the turbine building contained the systems shown in the equipment layout, Figure 5. Figures 6 through 9 are pictures of the equipment in the turbine building prior to decommissioning. A detailed physical description of the turbine equipment can be found in Reference 8 .

\section{Radiological Conditions}

In May 1979 the first BORAX-V facility radiological characterization took place. This characterization included radiation level measurements and surface contamination checks at various lccations within the turbine building (see Table 1). Measurements showed that the building surfaces contained no loose radioactive contamination. A detailed description of the radiological condition of the facility can be found in Reference 8 .

To comply with the INEL Low-Level Radioactive Waste Acceptance Criteria ${ }^{9}$ for waste disposal at Radioactive Waste Management Complex (RWMC), additional radiological characterization of known contaminated equipment inside the turbine building took place in February and May 1989. This survey penetrated all of the turbine building nuclear systems through flanges, pipe unions, couplings, and existing penetrations. Radiation measurements defined local radioactivity and samples of debris scraped from inside the system determined radioactive contarnination. When debris could not be scraped loose, smearing the surface with absorbent material provided a sample. The EG\&G Idaho Radiation Measurements Laboratory (RML) analyzed the debris and smears for isotopic content. ${ }^{10}$ The radiological analyses consisted of a gamma spectroscopic, and alpha and beta analyses. The data from these surveys are shown in Table 2 . All measurements in the turbine building were less than $0.1 \mathrm{mR} / \mathrm{h}$. A slightly higher level of $1-4 \mathrm{mR} / \mathrm{h}$ was found inside the turbine-generator system components. As in the 1979 radiological characterization, no loose contamination was found on the surfaces of the turbine building nor on the equipment housed in the turbine building.

\section{Hazardous Chemical Conditions}

Two underground storage tanks (USTs), Numbers $602-\mathrm{SW} 1$ and $602-\mathrm{SW} 2$, located near the southwest corner of the turbine building which supplied fuel oil to the turbine building heating system were sampled for waste profile analysis in September 1988. The contents of Tank Number $602-S W 1$ were determined to be hazardous waste fuel based on the concentration of arsenic which ranged from 2-10 ppm. Approximately 165 gal of fuel was pumped from the tank into 55-gal drums and transported to the Hazardous Waste Storage Facility (HWSF) located at the CFA-637 in July 1989. Tank 602-SW2 was empty and was not sampled in September 1988. The contents of a third UST, Tank Number $601-W$, located west of the reactor building were also sampled in September 1988. The contents of this tank were determined to be hazardous waste fuel based on a barium concentration of $170 \mathrm{ppm}$. Approximately $430 \mathrm{gal}$ of fuel was pumped from this tank and transported to the HWSF for disposal or storage in July 1989. 


$\begin{array}{llll}\text { ARA } & \text { Auxiliary Reactor Facility } & \text { PBF } & \text { Power Burst Facility } \\ \text { ANL-W } & \text { Argonne National Laboratory - West } & \text { PREPP } & \text { Process Experimental Pilot Plant } \\ \text { BORAX } & \text { Boiling Water Reactor Experiment } & \text { RWMC } & \text { Radioactive Waste Management Complex } \\ \text { CFA } & \text { Central Facilities Area } & \text { STF } & \text { Security Training Facility } \\ \text { EBR I } & \text { Experimental Breeder Reactor I } & \text { TAN } & \text { Test Area North } \\ \text { EBR II } & \text { Experimental Breeder Reactor II } & \text { TRA } & \text { Test Reactor Area } \\ \text { ICPP } & \text { Idaho Chemical Processing Plant } & \text { TREAT } & \text { Transient Reactor Test (Facility) } \\ \text { IET } & \text { Initial Engineering Test } & \text { WEDF } & \text { Waste Experimental Development Facility } \\ \text { LOFT } & \text { Loss-cf-Fluid Test (Facility) } & \text { WERF } & \text { Waste Experimental Reduction Facility } \\ \text { MWSF } & \text { Mixed Waste Storace Facility } & \text { WRRTF } & \text { Water Reactor Research Test Facility } \\ \text { NRF } & \text { Naval Reactor Facility } & \text { ZPPR } & \text { Zero Power Fhysics Reactor }\end{array}$

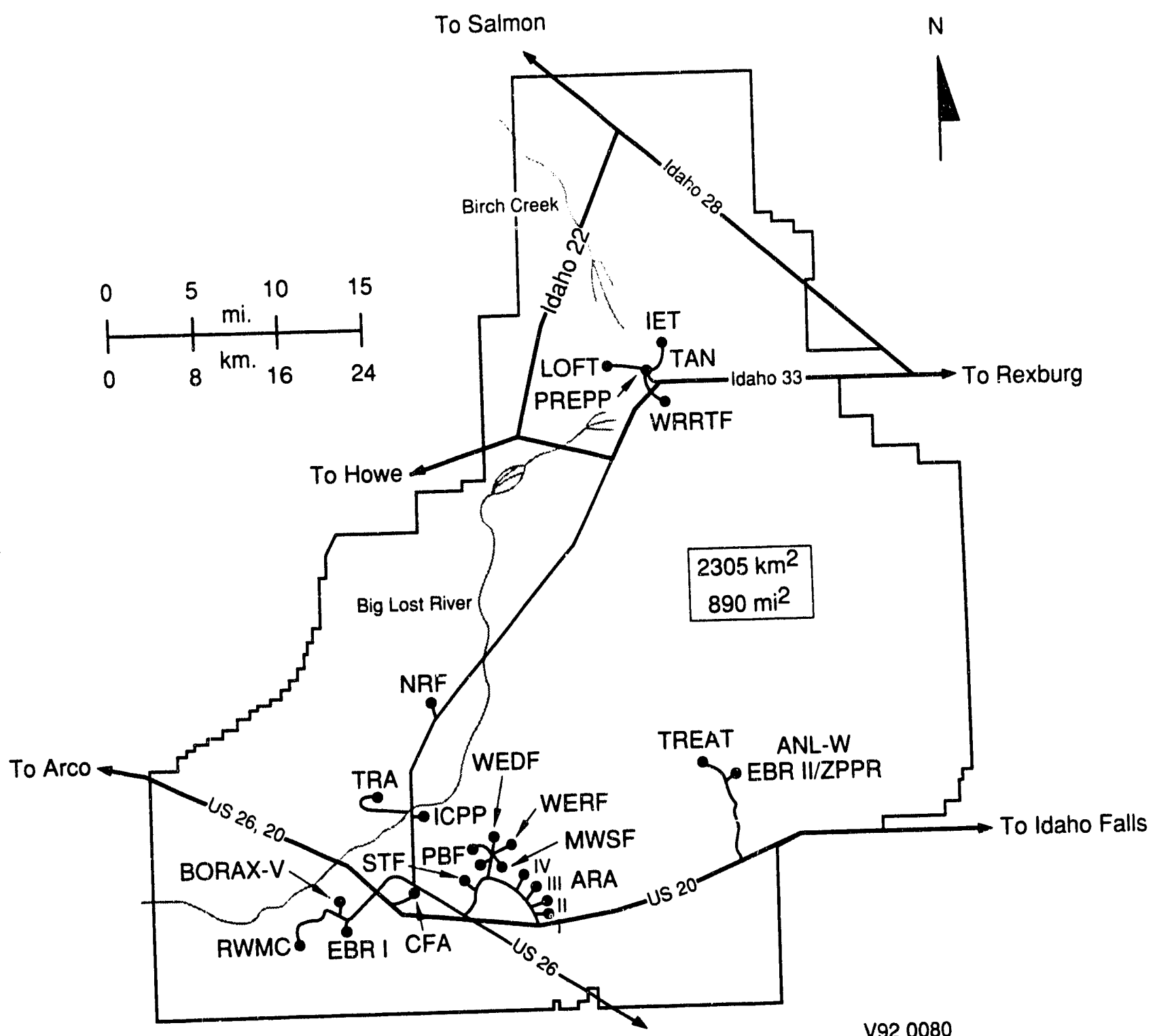

Figure 1. Location of BORAX-V facility within the INEL. 


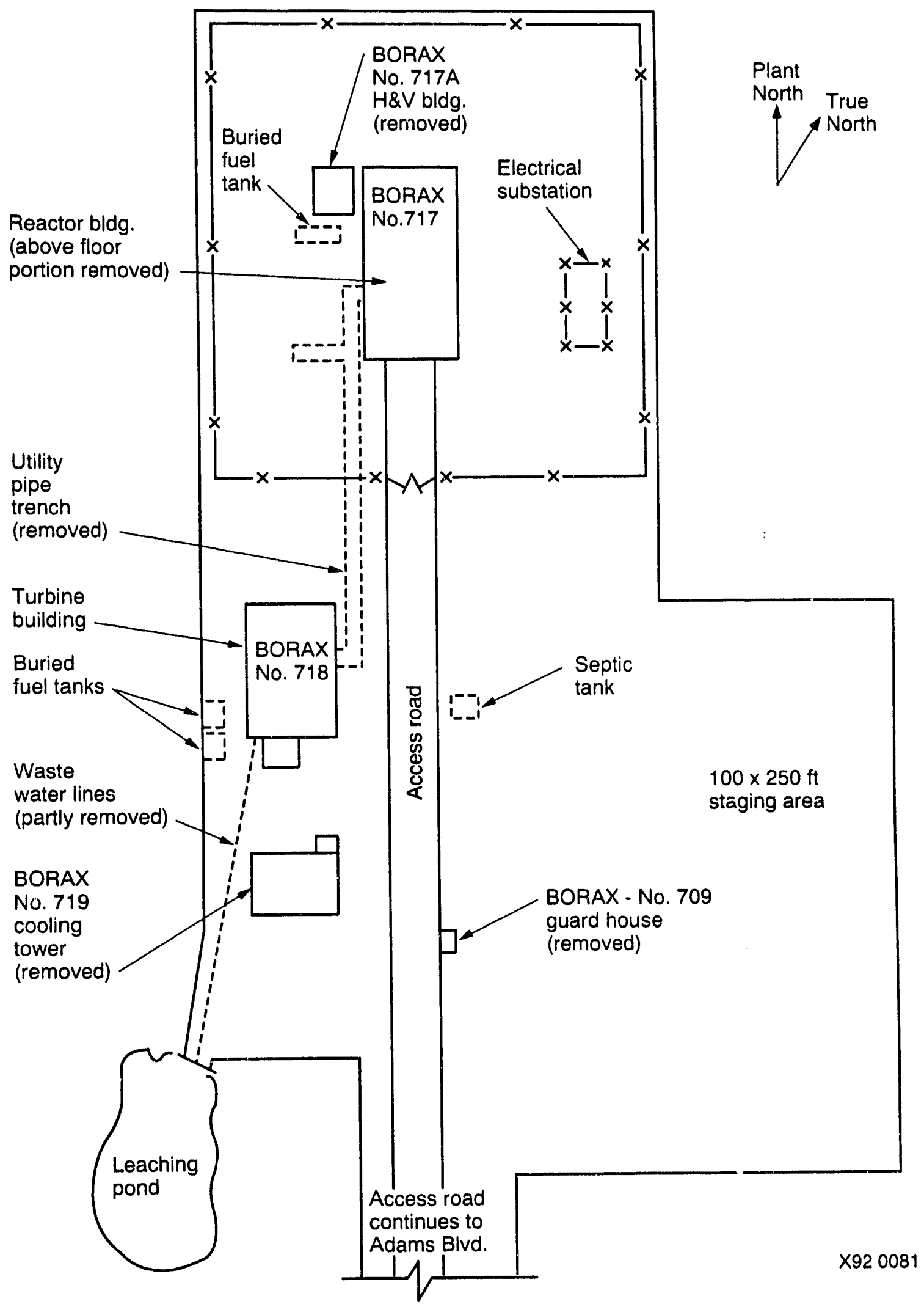

Figure 2. BORAX-V site boundary and layout. 


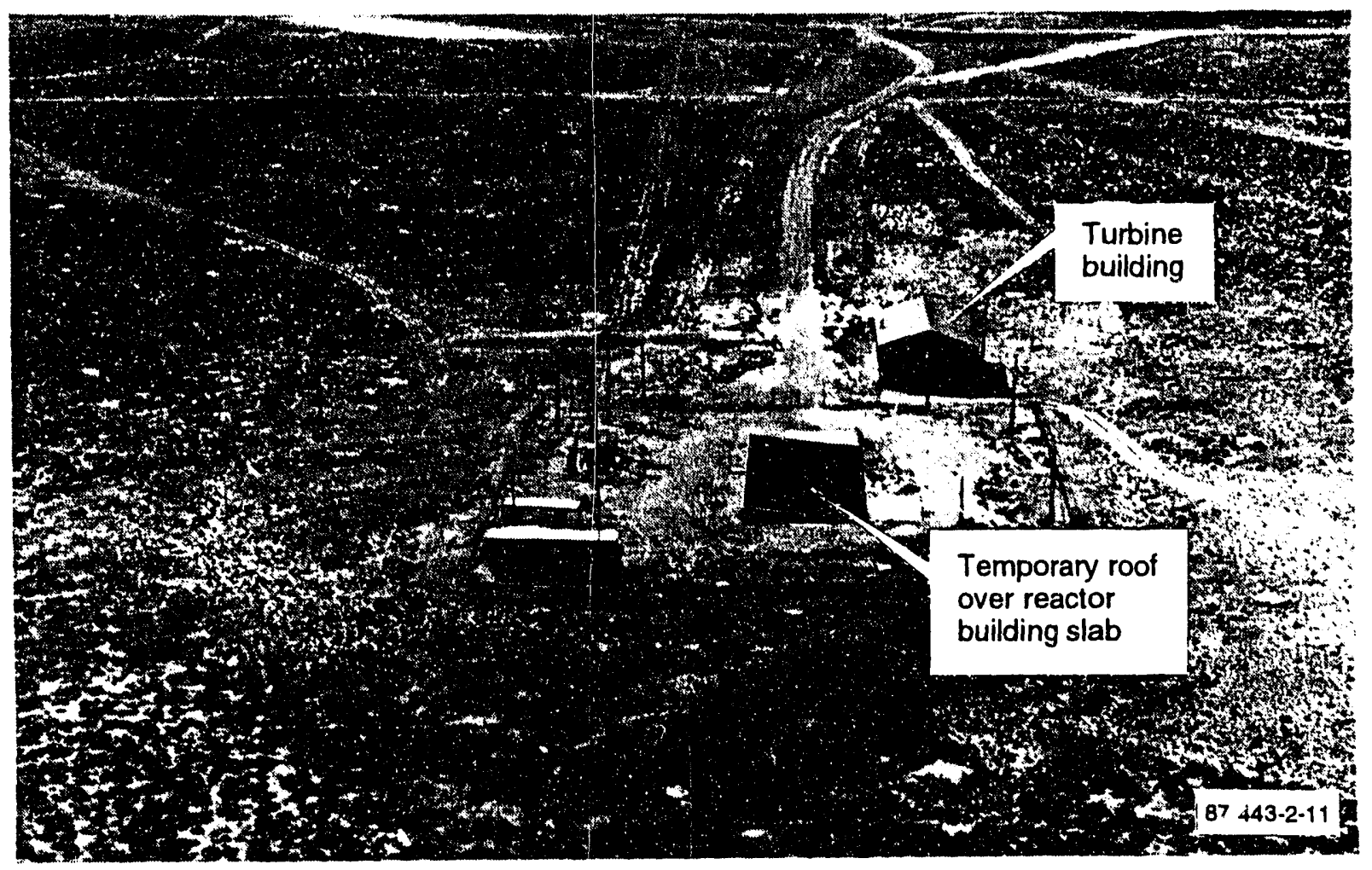

Figure 3. Aerial view of BORAX-V facility. 


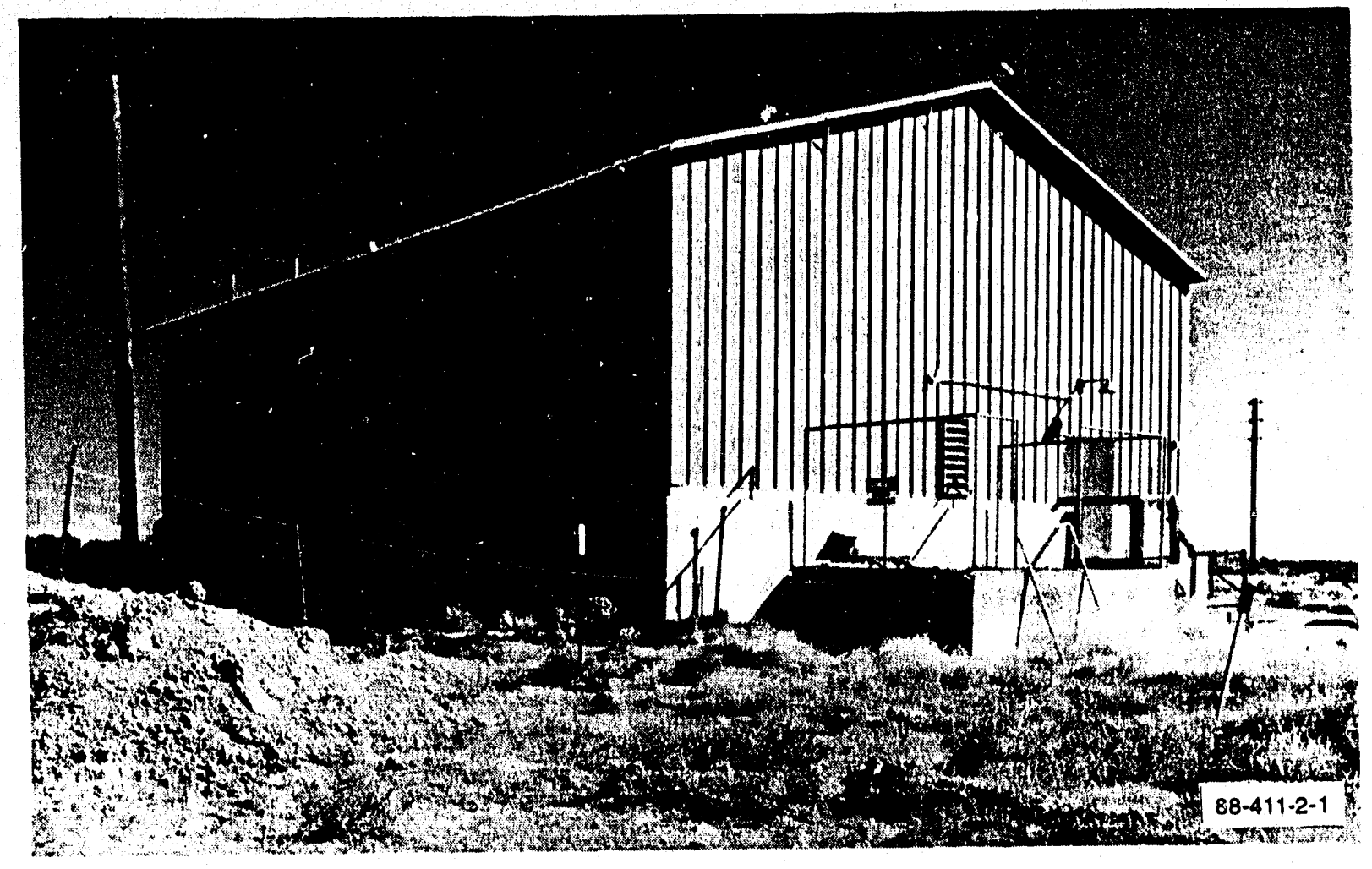

Figure 4. Turbine building, looking northeast. 


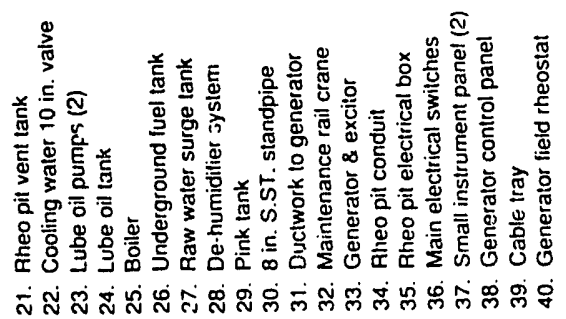
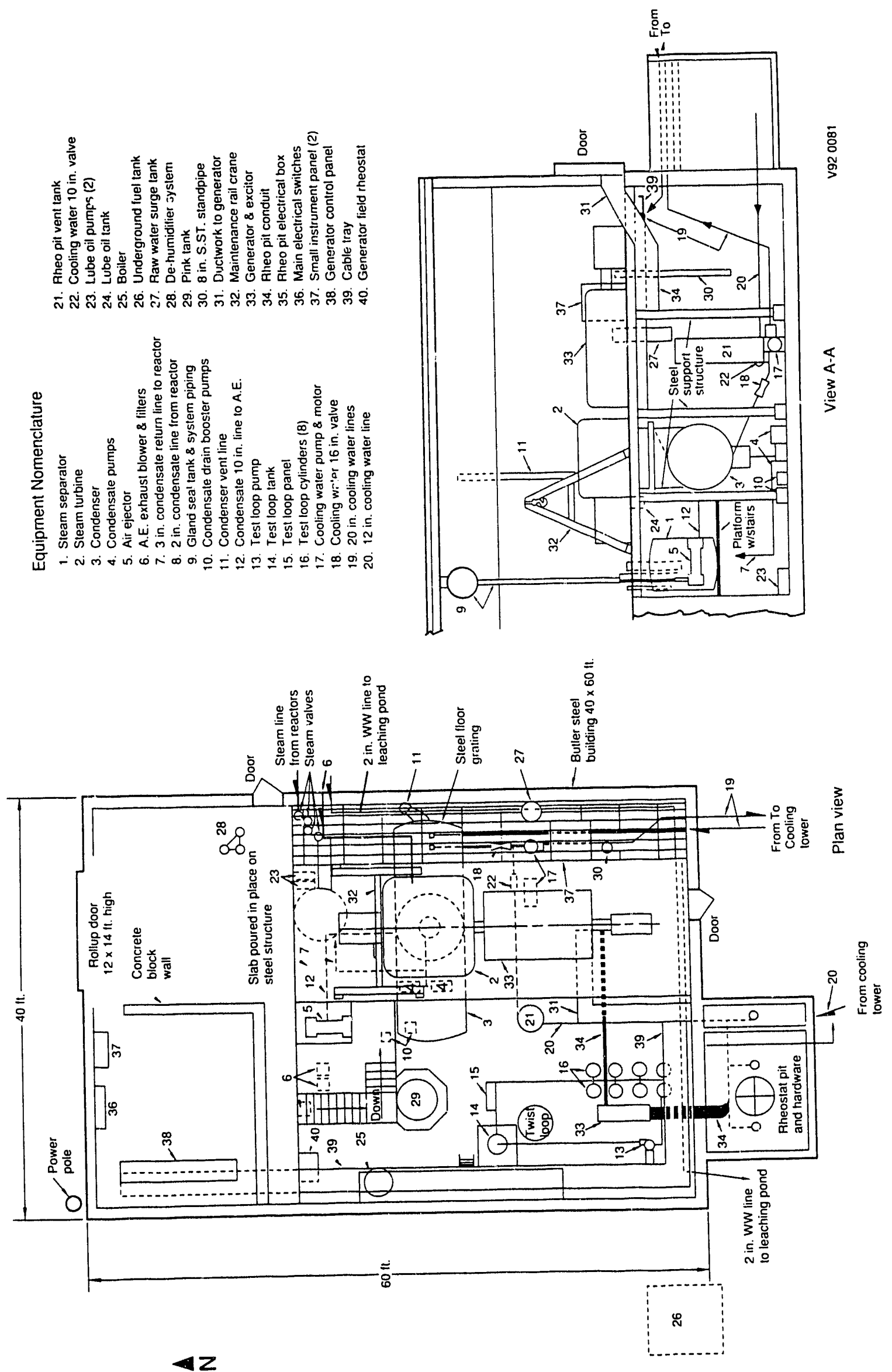


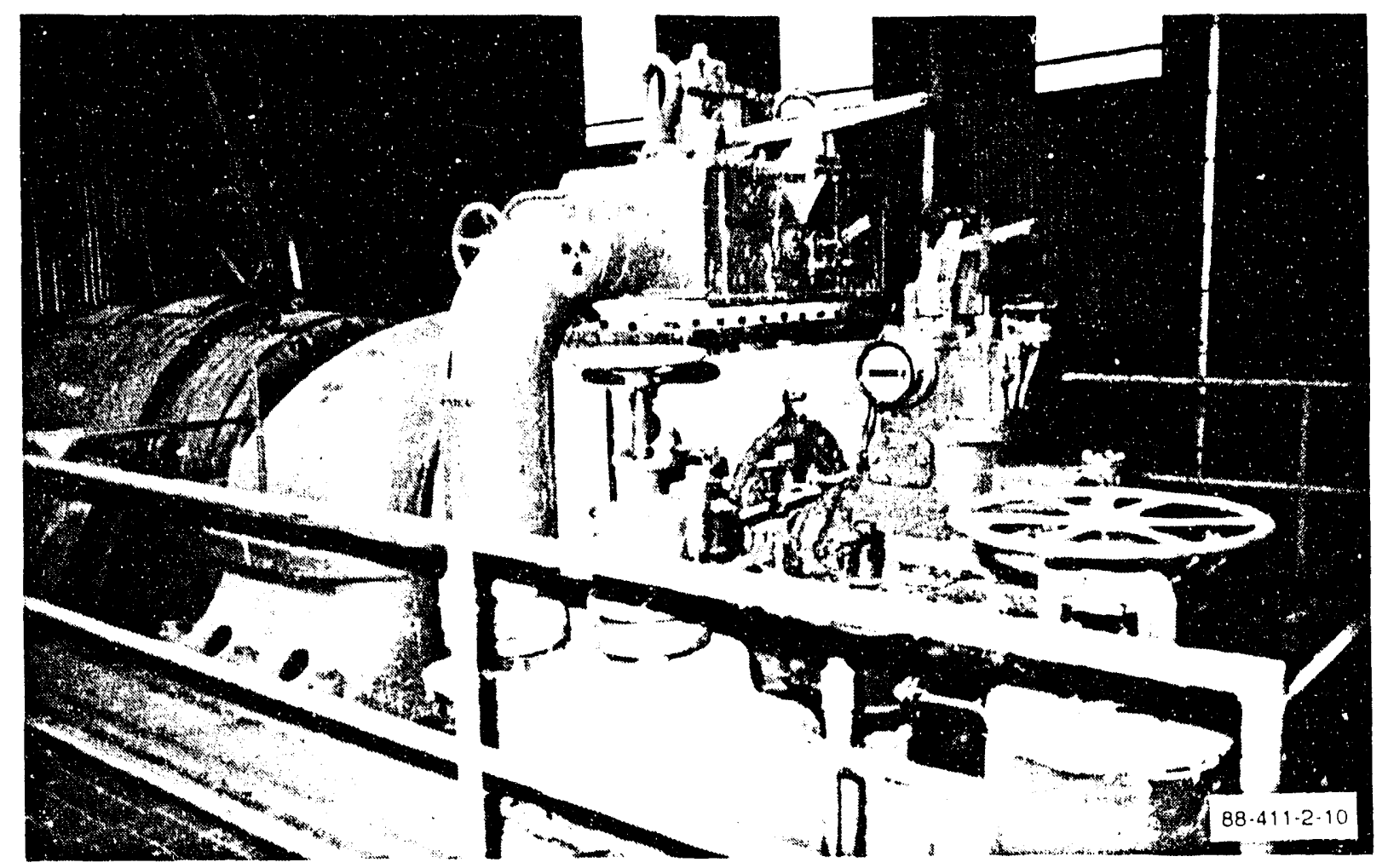

Figure 6. View of 1926 Westinghouse urbine-generator.

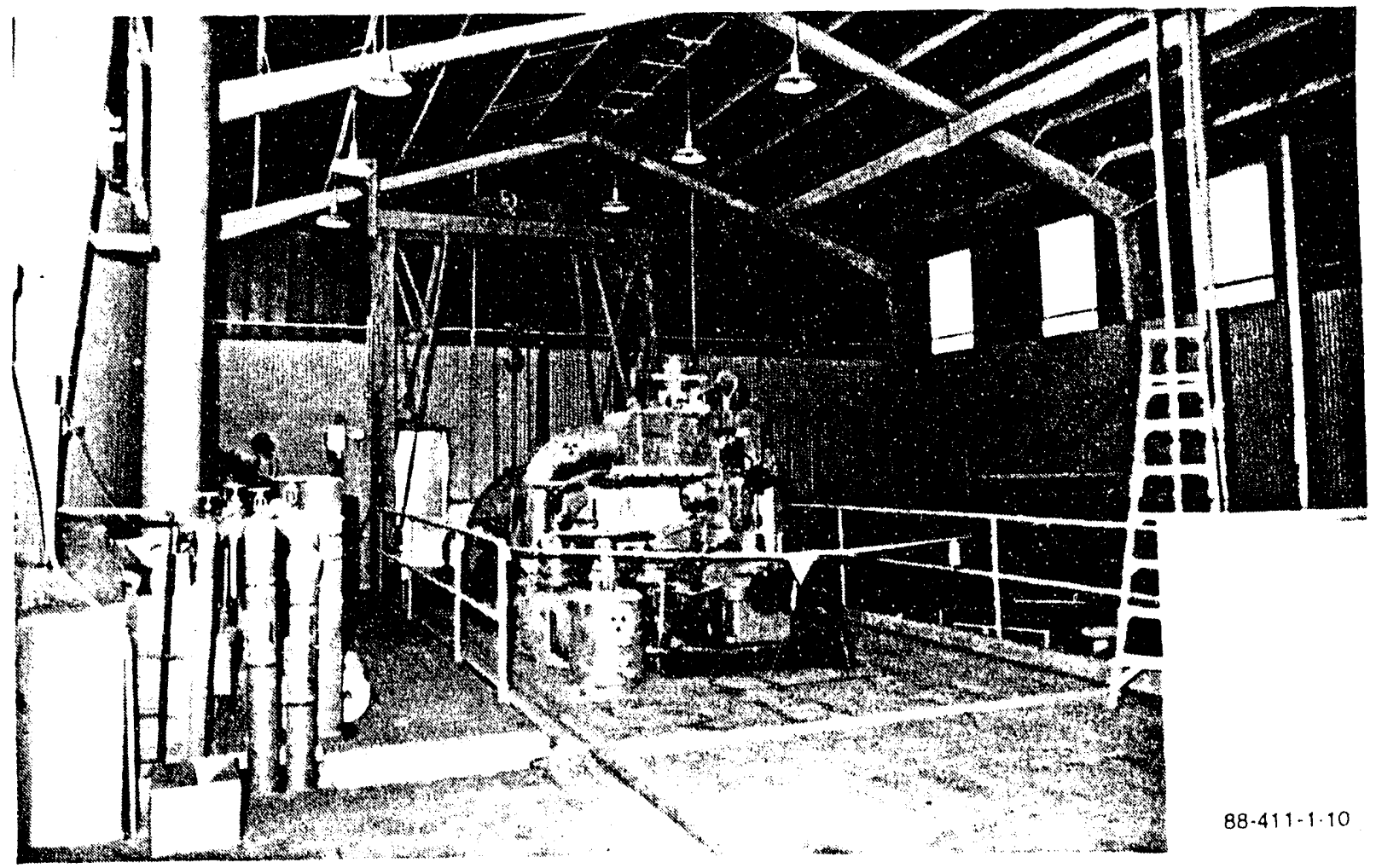

Figure 7. View of turbine building main floor. 


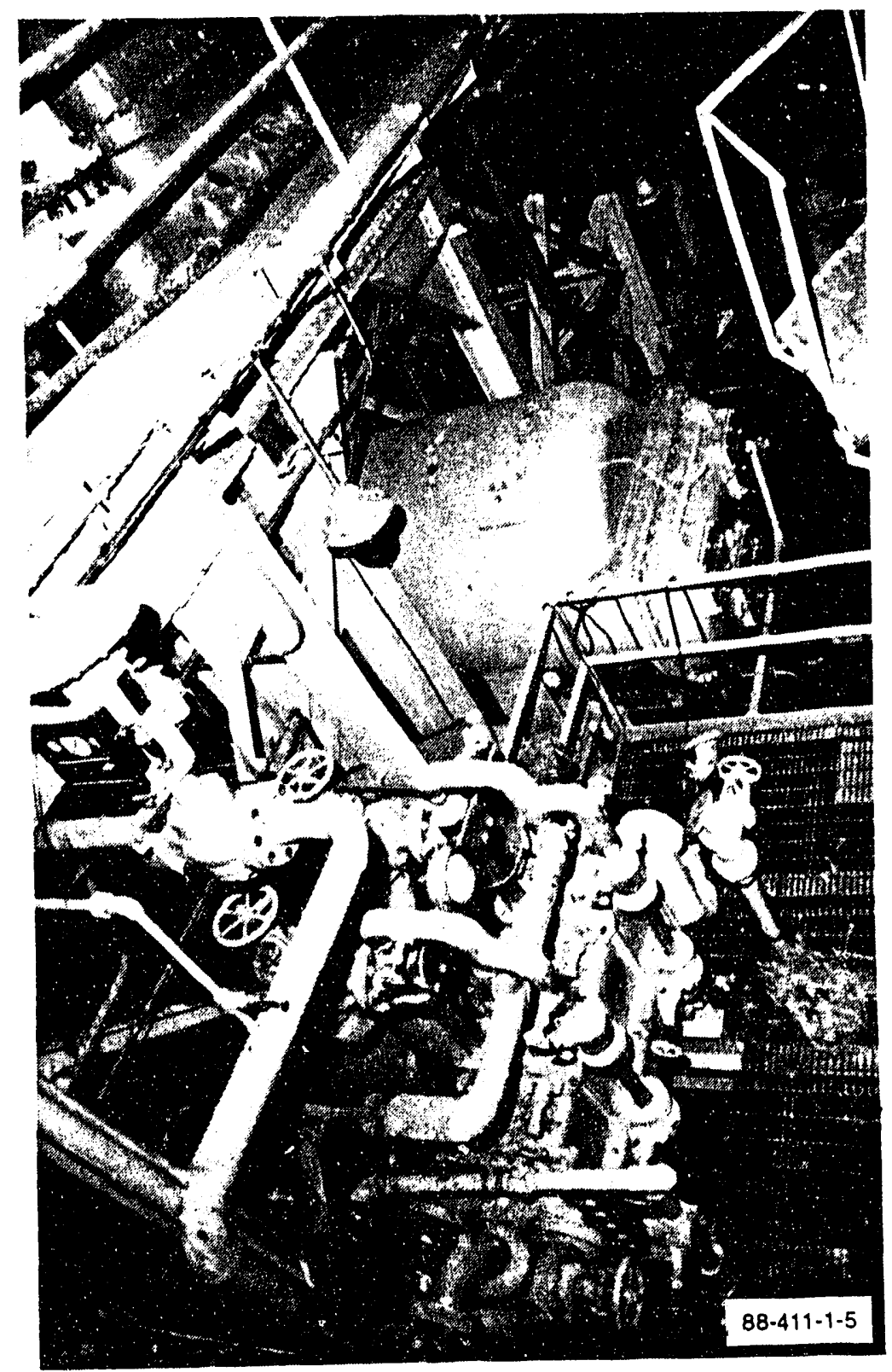

Figure 8. View of equipment in turbine building basement, looking south. 


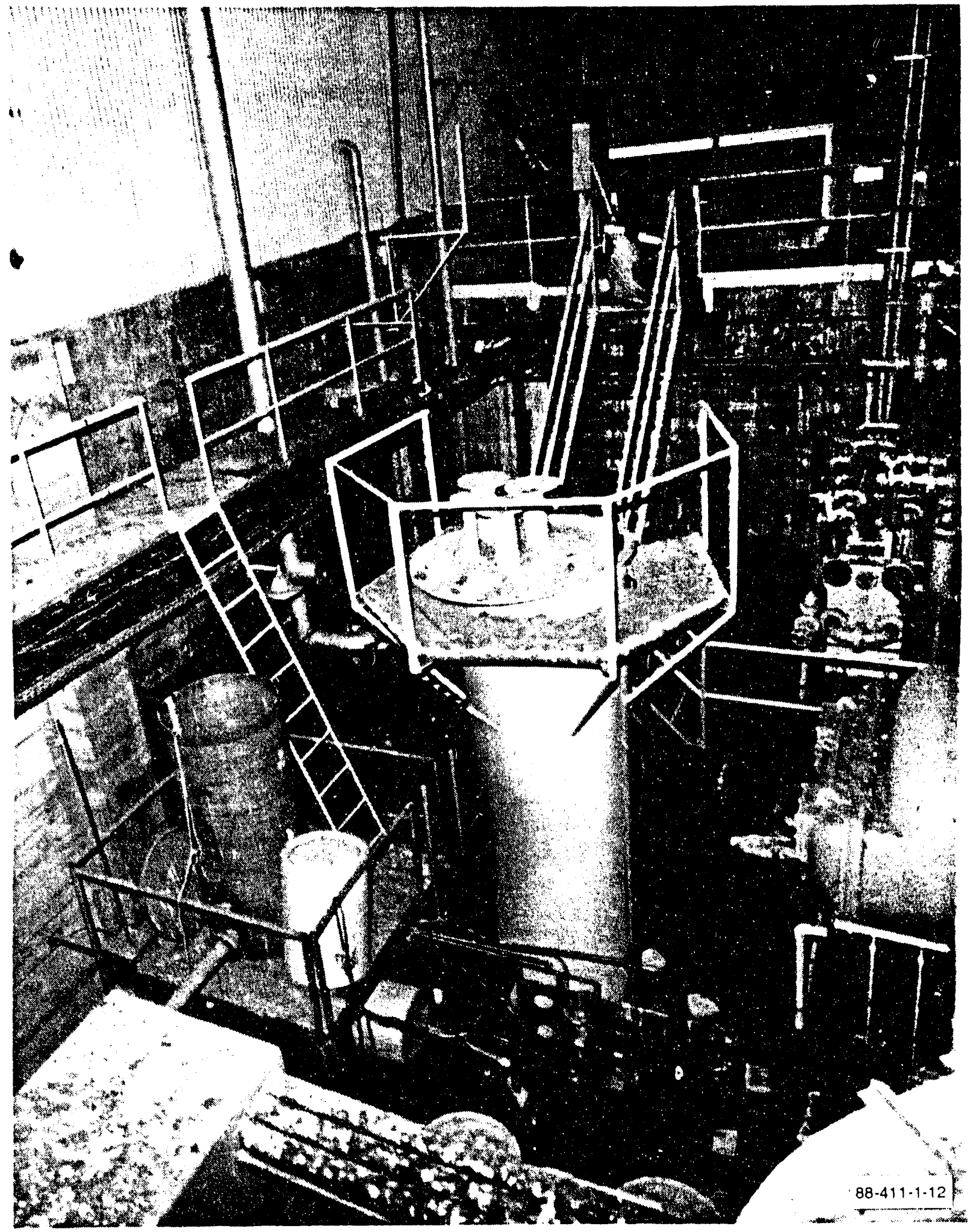

Figure 9. View of equipment in turbine building basement, looking north. 
Table 1. Results of May 1979 radiological survey of systems at the turbine building.

\begin{tabular}{llll}
\hline \multicolumn{1}{c}{ System } & System location & $\begin{array}{c}\text { Measured } \\
\text { radiation } \\
(\mathrm{mR} / \mathrm{h})\end{array}$ & $\begin{array}{c}\text { Isotope } \\
\text { identified in } \\
\text { debris or smear }\end{array}$ \\
\hline 1. Condensate & Lower level & $<0.1$ & None \\
2. Test loop & Lower level & $<0.1$ & None \\
3. Steam separator & Lower level & $<0.1$ & None \\
4. Condensate & Lower level & $<0.1$ & None \\
5. Gland seal tank & Overhead & $<0.1$ & None \\
6. Condenser & Lower level & $<0.1$ & None \\
7. Air ejector exhaust & Lower level & $<0.1$ & None \\
8. Steam valves & Upper level & $<0.1$ & None \\
9. Pink tank & Lower level & $<0.1$ & None \\
10. Turbine & Upper level & $<0.1$ & None \\
11. Dehumidifiers & Upper level & $<0.1$ & None \\
\hline
\end{tabular}


Table 2. Results of 1989 radiological surveys at the turbine building.

\begin{tabular}{lll}
\hline \multicolumn{1}{c}{ Type of survey } & Survey location & \multicolumn{1}{c}{ Results } \\
\hline Smears (8) & Turbine top internals & $\begin{array}{l}\text { No detectable alpha } \\
15 \mathrm{pCi} / \mathrm{sample} \text { Co-60 }\end{array}$ \\
& & $30 \mathrm{pCi} / \mathrm{sample}$ Cs-137 \\
Masslin wipe (4) & Turbine top internals & No detectable alpha \\
& & $4 \mathrm{pCi} / \mathrm{sample}$ Co-60 \\
& & $42 \mathrm{pCi} / \mathrm{sample}$ Cs-137 \\
& & $14 \mathrm{pCi} / \mathrm{sample}$ Th-234 \\
HP-210 Frisk & Turbine top and main & Maximum of $15,000 \mathrm{cpm}$ \\
(20\% efficiency) & turbine internals & beta/gamma at several \\
& & spots. Average activity \\
Smears (8) & & $1,000-5,000 \mathrm{cpm}$
\end{tabular}

One electrical transformer in the turbine building was found to contain oil contaminated with polychlorinated biphenyls (PCBs) and was removed by Power Management in August 1988.

The chemical characterization of the turbine building facility systems took place in the spring of 1989. Residue samples from the selected systems were analyzed for volatile, semi-volatile, PCBs, and heavy metal content. The sample anal-

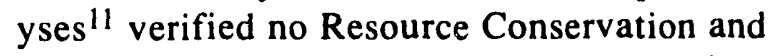
Recovery Act (RCRA) prohibited materials above regulatory limits (see Reference 8 ) in any of the radioactively contaminated systems.

Additional analysis of components with potential hazards showed:
- Some radioactive contamination in the asbestos insulation covering the steam handling systems

- Small amounts of mercury in components of some instrumentation which were radiologically clean

- 10 lead bricks and a small amount of lead plates which were radiologically clean

- $100 \mathrm{gal}$ of oil from the lube oil system which were sampled and analyzed for PCBs, hazardous materials, and radiological contaminants, and were found to be free of any contaminants. 


\section{DECOMMISSIONING OBJECTIVES AND WORK SCOPE}

\section{Objectives}

The objectives of this project were to prepare the BORAX-V area so that it would present no radiological, health, or safety hazard to the public or to INEL personnel, and to condition the area so that it would be available for unrestricted reuse. Upon completion of these objectives the area would be removed from the Surplus Facilities Management Program priority list.

\section{Work Scope}

The BORAX-V D\&D project was divided into two phases: (1) turbine building, and (2) reactor building and remaining other systems. The work scope presented below addresses the turbine building phase:

The D\&D process for the turbine building was divided into the following tasks:

1. Remove and dispose of the asbestos from turbine building. This included removing asbestos insulation from the steam separator, and removing the steam turbine and associated piping with minimum disturbance to the asbestos insulation.

2. Remove and dispose of three underground heating fuel storage tanks and associated piping.

3. Remove all other equipment from the turbine building.

4. Dismantle the turbine building metal structure.
5. Dispose of the removed equipment and dismantled building materials.

6. Excavate, package, and dispose of the remaining waste water piping on the west side of the turbine building running to the leach pond.

7. Decontaminate concrete surfaces of the turbine building foundation to releasable levels using intrusive techniques such as chipping and use of air-driven needle guns.

8. Demolish and backfill the turbine building foundation.

9. Reseed the area with native grasses and install a permanent D\&D marker. (This activity will be accomplished in conjunction with the reactor building restoration activity.)

10. Prepare a final report of the D\&D of the turbine building.

The D\&D tasks were accomplished using Site Work Release (SWR) detailed integrated planning that complied with safety, quality, and environmental requirements and regulations. Safe work permits were utilized to ensure that workers were adequately protected through the use of proper personal protective equipment (PPE) while at the job site. Routine surveillance of workers handling radioactively contaminated and/or asbestos containing materials by health physics (HP) technicians and industrial hygienists (IHs) helped to further control hazardous working conditions. Total personnel radiation exposure was limited to background doses and there was no inhalation of asbestos fibers. 


\section{WORK PERFORMED}

\section{Project Management/Project Engineering}

EG\&G Idaho Environmental Restoration Program (ERP) provided D\&D project management and project engineering. Project managers were responsible for planning, development of project documentation, coordination, and overall direction of the project, as well as all of the associated budgeting, scheduling, and reporting requirements. The tasks to complete the BORAX-V turbine building $D \& D$ are shown in the Work Breakdown Structure (WBS), Figure 10.

Decision Analysis. A decision analysis for the BORAX-V facility (see Reference 4 ) was performed in 1984. Five alternatives were considered and the sections of each alternative dealing with the turbine building are listed below:

Alternative 1-Take no action; continue surveillance and maintenance mode.

Alternative 2-Perform limited demolition. The turbine building would receive a general cleanup of loose equipment to facilitate surveillance and maintenance. The stored drums, concrete block wall, and large pink tank would be removed from the turbine building. The building contains radioactive contamination and would require surveillance and maintenance.

Alternative 3-Facility dismantlement. All radiologically contaminated metal material within the turbine building would be removed, packaged, and processed at the Waste Experimental Reduction Facility (WERF) or buried at RWMC. All contaminated concrete would be removed and buried at RWMC. All uncontaminated material with no salvage value (except concrete) would be removed and buried at the sanitary landfill. The turbine building would be placed in a staging area for disposition by INEL property management. Uncontaminated concrete below $6 \mathrm{ft}$ from the surface would be left in place and uncontaminated concrete above this level would be removed and used for fill below the $6-\mathrm{ft}$ level.

Alternative 4-Limited demolition of reactor building and total dismantlement of the of remainder of facility. The turbine building would be decommissioned as specified in Alternative 3 .

Alternative 5-Stabilization of reactor building in place and total dismantlement of remainder of facility. The turbine building would be decommissioned as specified in Alternative 3.

The alternatives were considered and compared based on estimated cost, material reuse, facility reuse, surveillance and maintenance costs, volume of waste generated, hazards to D\&D workers, short-term impact to INEL personnel and operations, and long-term impact to the public. Alternative 5 was recommended after comparing the advantages and disadvantages of each alternative.

A second decision analysis for the BORAX-V facility (see Reference 7) was performed in 1988 to consider the condition of the facility as of October 1, 1988, and to address the current environmental issues in each of the five decommissioning alternatives.

Alternative 1-Take minimum action. The facility would remain under surveillance. The turbine building would be surveyed and sampled for hazardous materials followed by appropriate disposition. Environmental concerns prompt the removal of these materials. Maintenance would be performed to keep the facility in a safe and stable condition.

Alternative 2-Limited demolition. The turbine building would receive a general cleanup of loose equipment to facilitate surveillance and maintenance. The large pink tank would be removed from the turbine building. (The purpose of the large pink tank is unknown. All hazardous and toxic materials would be removed, including all asbestos. Surveys indicate no radioactive or chemical contamination, and the tank is not 


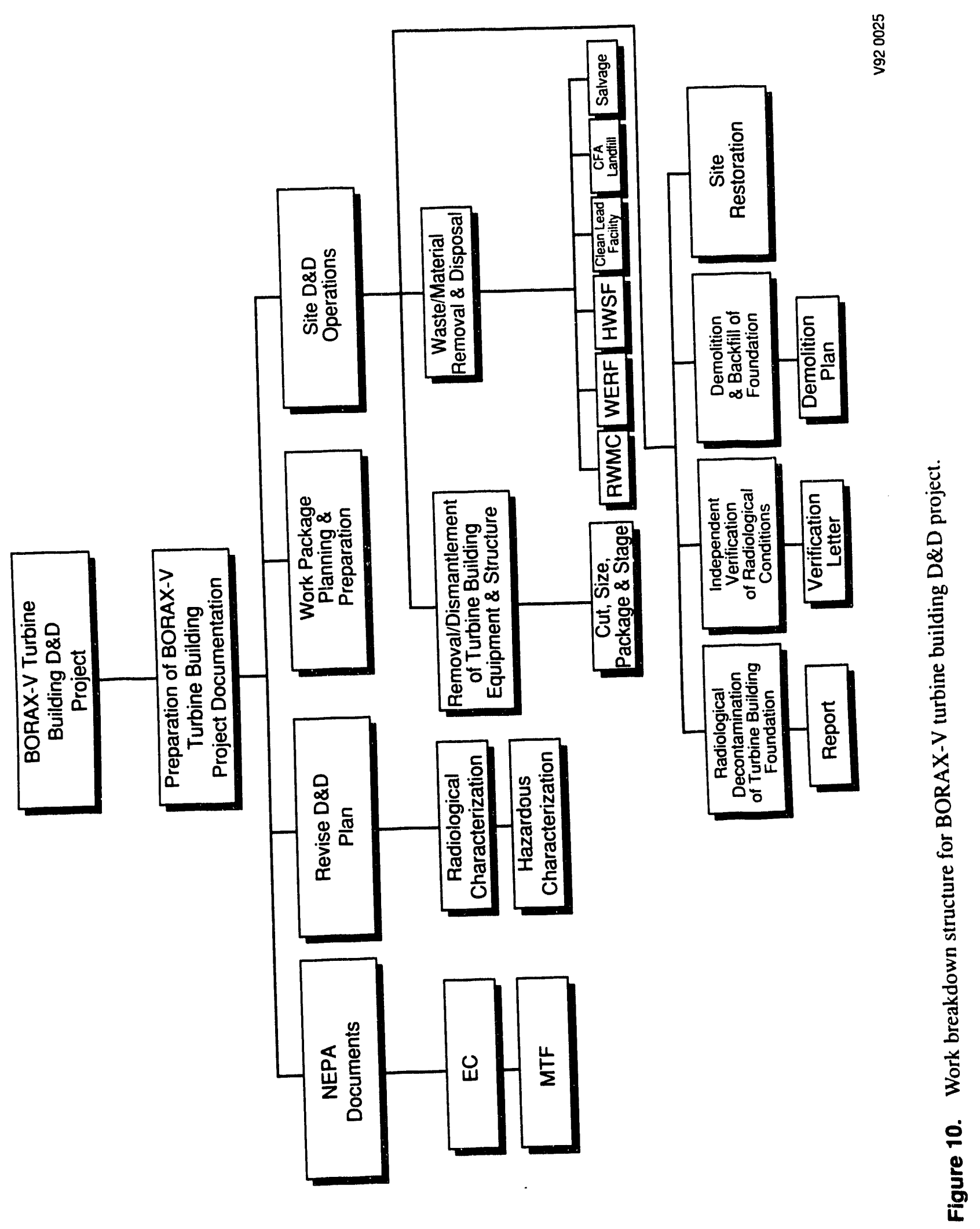


associated with the turbine operation.) This building is radioactively contaminated and would require surveillance and maintenance.

Alternative 3-Facility dismantlement. The turbine building would be surveyed for hazardous and toxic material followed by appropriate disposition. The turbine building and all its associated systems would be removed. All radiologically contaminated metal material within the turbine building would be removed, packaged, and processed at WERF or buried at RWMC. All contaminated concrete would be removed and buried at RWMC. All uncontaminated material with no salvage value (except concrete) would be removed and buried at the sanitary landfill. Salvageable, uncontaminated material, including the turbine building gantry crane, and the turbine building would be placed in a staging area for disposition by INEL Property Management. Uncontaminated concrete below $6 \mathrm{ft}$ from the surface would be left in place and uncontaminated concrete above this level would be removed and used for fill below the 6-ft level. Following D\&D of the entire area, the land would be contoured and planted with crested wheatgrass.

Alternative 4-Limited demolition of reactor building and total dismantlement of remainder of facility. The turbine building would be decommissioned as specified in Alternative 3.

Alternative 5-Stabilization of reactor building in place and total dismantlement of remainder of facility. The turbine building would be decommissioned as specified in Alternative 3 except contaminated material from the turbine building would be placed in the reactor building equipment pits

The alternatives were considered and compared based on estimated cost, material reuse, facility reuse, surveillance and maintenance costs, volume of waste generated, hazards to D\&D workers, short-term impact to INEL personnel and operations, and long-term impact to the public. Alternative 5 was recommended after comparing the advantages and cisadvantages of each alternative.
Final Decision Analysis. In a May 1989 let$\operatorname{ter}^{12}$ to the Fuel Processing and Waste Management Division of DOE-ID from EG\&G Idaho ERP manager, it was recommended that total dismantlement of the BORAX-V facility be performed rather than entombment of the reactor foundation. The reasoning was that an entombed facility would still require surveillance and maintenance, it would produce a long-term burial site, and there would be no guarantee that future regulations would allow the site to remain entombed. A June 1989 letter $^{13}$ from the acting assistant manager for DOE-ID Nuclear Programs to the EG\&G Idaho ERP manager concurred with the recommendation for total dismantlement alternative for the BORAX-V facility.

The change to total dismantlement D\&D alternative for BORAX-V facility changed the location for disposal of the turbine building radiologically contaminated equipment from being buried in the reactor building equipment pits to being sent to WERF and RWMC.

The D\&D Plan provided the details for the accomplishment of the work scope, cost estimates, and both a safety and environmental evaluation. Work package preparation started in 1991 using the D\&D plan. The Labor/Equipment Operations and South INEL Maintenance Operations group prepared the SWRs and associated integrated planning.

D\&D Plan and Work Packages. A D\&D Plan was first published in September 1979 (see Reference 3) and Revision 1 (see Reference 5) was issued in April 1985. Revision 2 (see Reference 6) was released in November 1988 reflecting the limited D\&D activities performed between 1985 and 1988. Revision 3 (see Reference 8) to the D\&D Plan was issued in September 1990 incorporating the decision for total dismantlement of the facility and splitting the D\&D of the turbine and reactor building into two separate phases. The D\&D Plan addressed the details of the project such as the system descriptions, radiological and chemical characterization data, release criteria and requirements, WBS, equipment removal planning, potential hazards to workers, and projected waste volumes. Estimated 
cost and schedule to perform the project are also included in the plan. Evaluations were provided for environmental and safety considerations. Review and approval of plan were obtained from the Environmental, Safety, and Quality Department, Waste Management 'rograms Groups, and from DOE-ID.

Work packages (SWR:) with detailed integrated planning were prepared for each of the tasks by the CFA Program Support Group with review and approval by Safety (industrial and rad-con), the D\&D project manager, and the facility manager. A demolition plan for the turbine building corcrete foundation was prepared and reviewed and approved by Safety, D\&D Programs, and DOE-ID. Photography of the D\&D tasks was performed by EG\&G Idaho Photographic Services personnel for project documentation.

\section{Site Preparation}

The EG\&G Idaho Safety and Environmental Program groups provided the reviews and approvals of the D\&D Plan, work packages, and safety engineering criteria. A lifting fixture was designed and a procedure written by EG\&G Idaho Mechanical Engineering unit for removing the generato: stator from the turbine building.

The National Envirsninental Policy Act (NEPA) review for this project began with the submittal of an Environmental Checklist ${ }^{14}$ (EC) to the EG\&G Idaho Environritental Assessment and Permitting Unit in February 1990. A memorandumto-file ${ }^{15}$ (MTF) was subsequently prepared and transmitted to DOE-ID for review in March 1990. The MTF was approved by DOE Headquarters (DOE-HQ) in July 1990. The determination that a MTF satisfied the NEPA documentation requirements allowed the $D \& D$ of the turbine building to proceed.

A 40-ft trailerhouse was located southeast of the turbine building to serve as the D\&D field office for the BORAX-V D\&D project. A phone was provided in the trailer by tapping into a phone line that ran into the reactor building area. Electri- cal power and lighting were still available, as the electrical substation located near the reactor building was still operational.

\section{Decommissioning Operations and Waste Disposal}

Asbestos Containing Material (ACM). Trained asbestos workers removed ACM from the steam separator, steam turbine, associated piping, and from other areas found to have $\mathrm{ACM}$ previously identified during a survey of the turbine building. The radiologically contaminated ACM was packaged per requirements and shipped to RWMC for burial as low-level waste. The uncontaminated $A C M$ was packaged per requirements and shipped to the CFA landfill for disposal. This work was performed under an approved MTF for generic asbestos removal. ${ }^{16}$

Steam Separator. The steam separator (see Figure 5, Item Number 1) was removed, packaged for shipment, and transported to WERF for size reduction and ultimate disposal at RWMC.

Steam Turbine. The steam turbine (see Figure 5, Item Number 2) was disconnected from the condenser vessel and turbine-generator and then disassembled into three sections with the ACM insulation intact (see Figure 11). The three sections of the steam turbine were lifted out through an opening made in the turbine building roof (see Figures 12 and 13), packaged per requirements (Reference 9), and shipped to RWMC for burial as low-level waste.

Pink Tank. The pink tank (see Figure 5, Item Number 29) was torch cut from its mounting brackets and lifted through an opening in the roof (see Figure 14). The tank was radiologically clean and was transported to the CF.A excess yard for salvage.

Test Loop System. The test loop system consisting of a tank, pump, valves, piping, air storage cylinders, and instrument panel (see Figure 5, Item Numbers 13-16) was dismantled, removed from the turbine building, and the radiologically clean materials transported to the CFA excess yard for salvage. The eight air cylinders were 


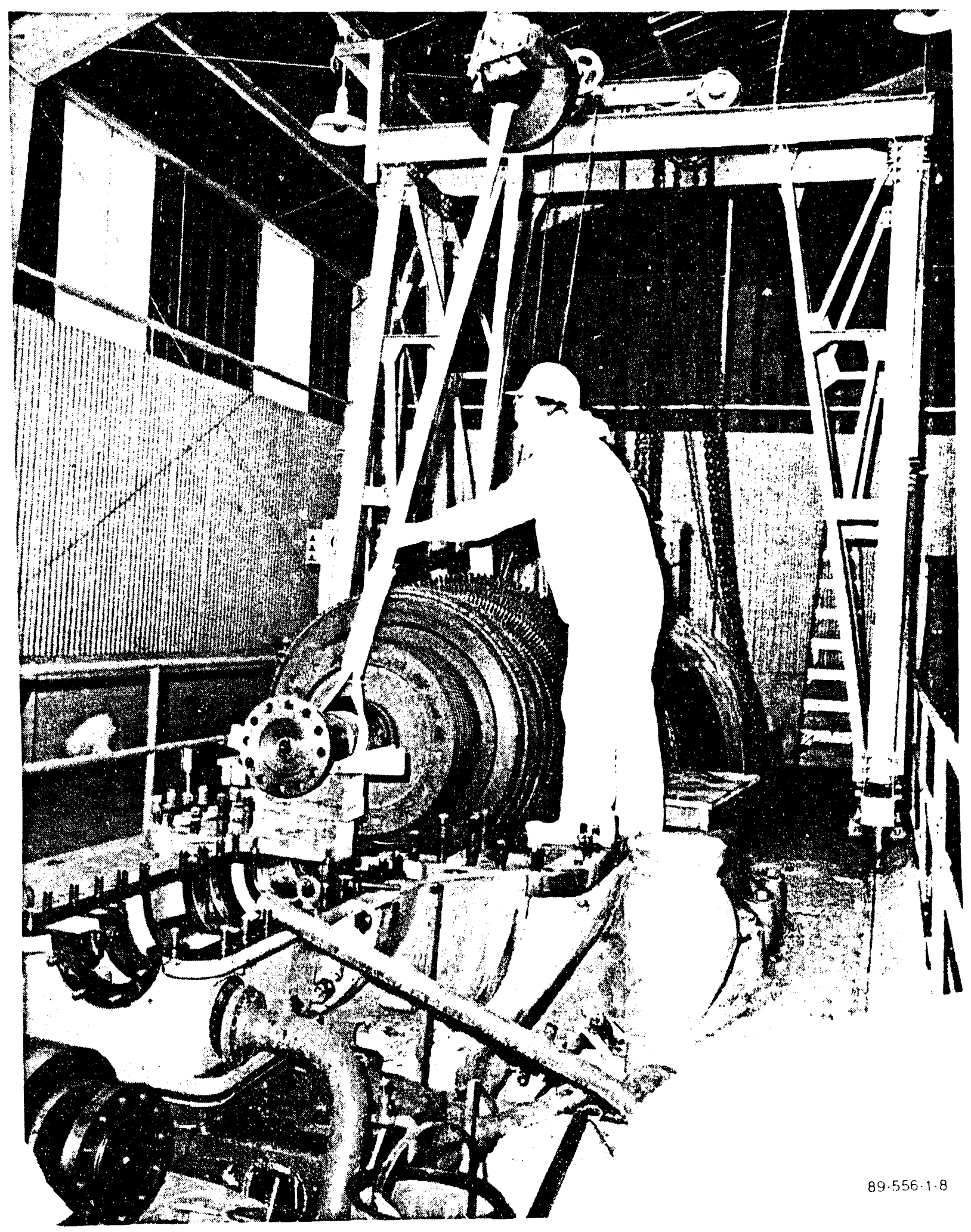

Figure 11. Disassembly of steam turbine assembly. 


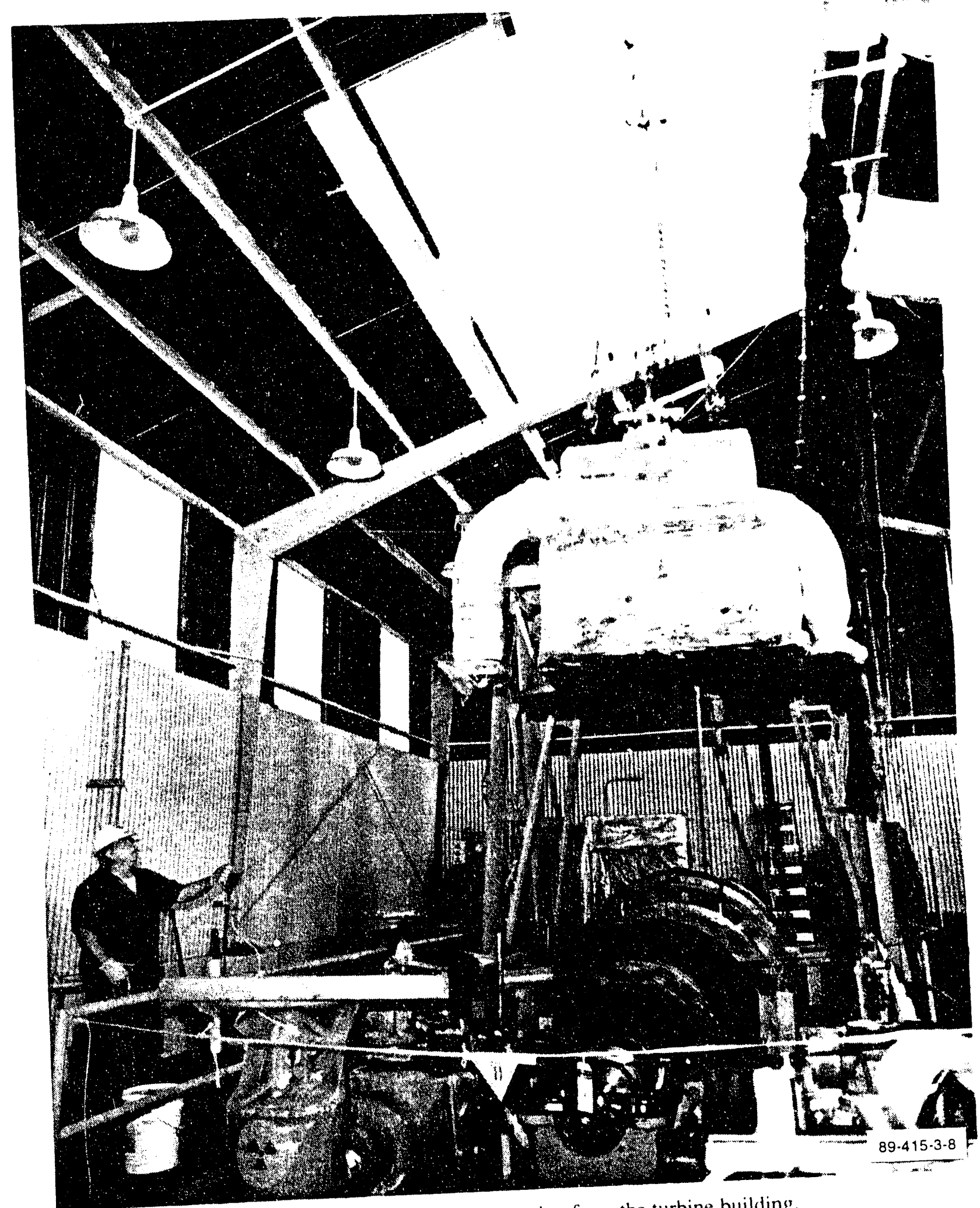

Figure 12. Removal of the steam turbine upper casing from the turbine building. 


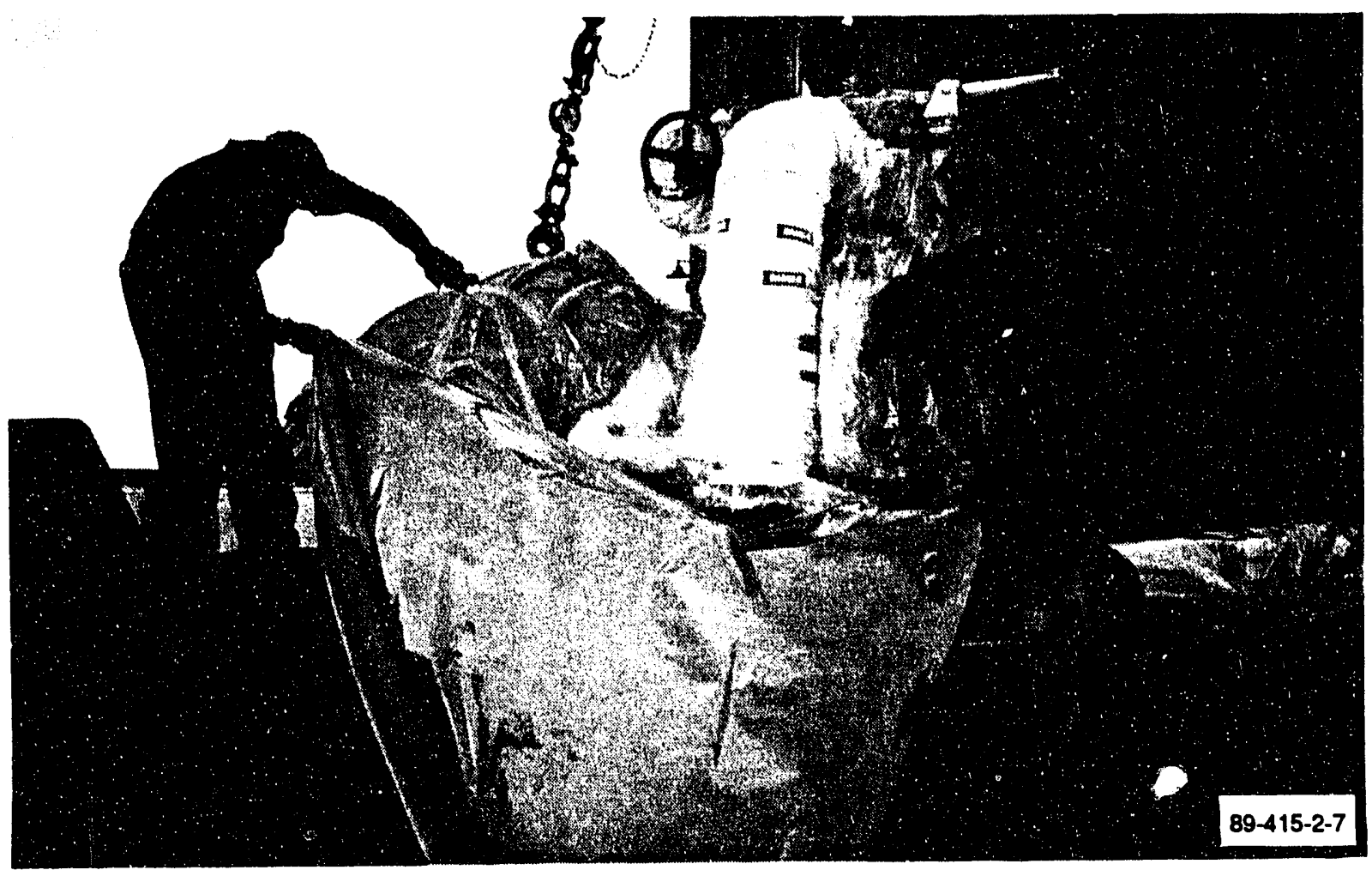

Figure 13. Preparing the steam turbine upper casing for shipment to RWMC. 

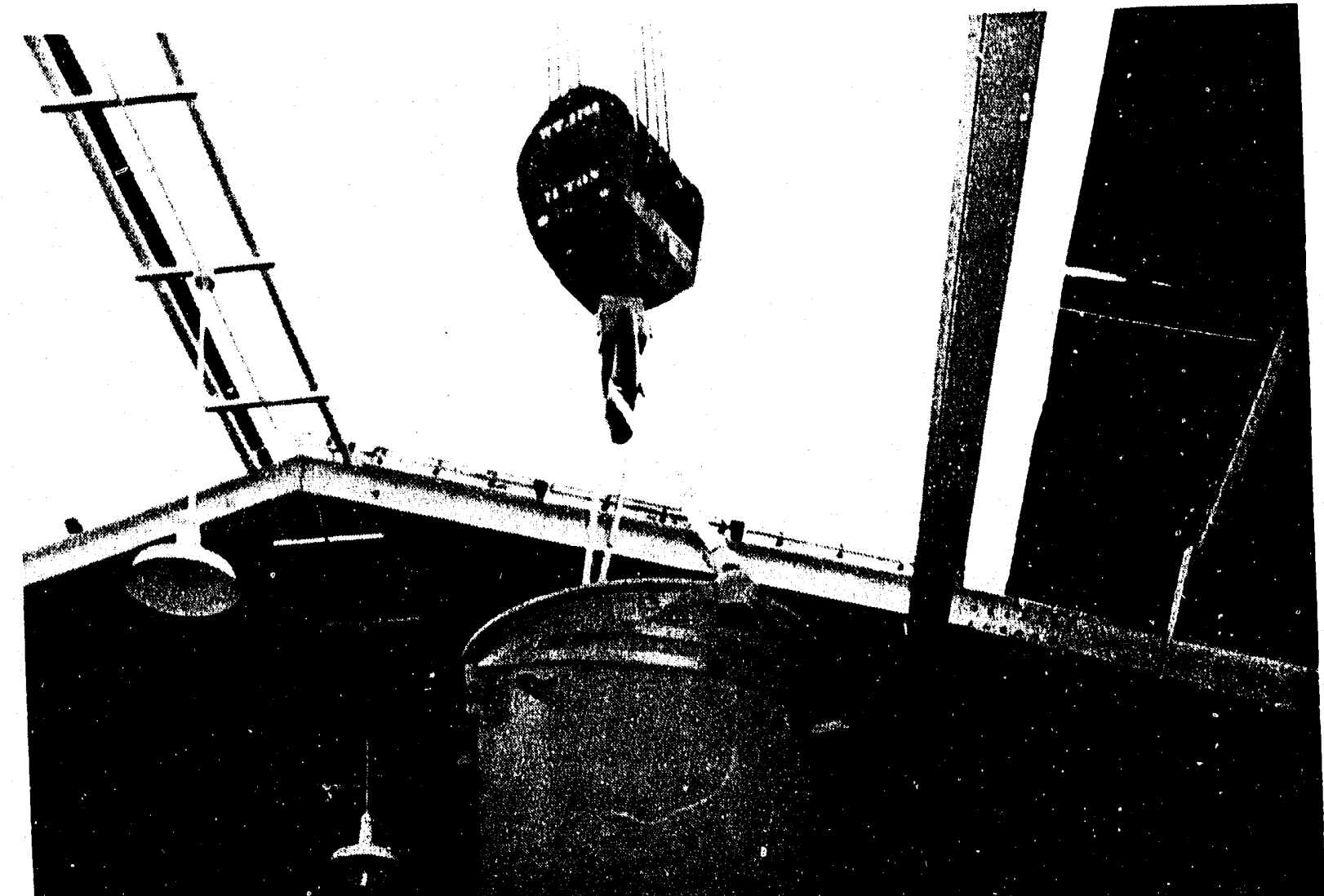

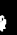

Figure 14. Removal of the pink tank from turbine building. 
torch cut in half to meet the CFA landfill size requirements and transported to the landfill for disposal.

Lube Oil System. The oil was drained from the lube oil system in 1989 sampled and analyzed for PCBs, hazardous materials, and radioactive contaminants. Sample analyses results showed the oil to be free of contaminants and the oil was disposed of as oil to be burned for energy recovery. The lube oil system pumps, tank, and piping (see Figure 5, Item Numbers 23 and 24) were disconnected, sized, and transported to the CFA landfill for disposal.

Water Rheostat System. The water rheostat system components (see Figure 5, Item Numbers $20-22,34$, and 35), associated piping, conduit, and cables were dismantled, sized, and removed from the turbine building. The copper cables were transported to the CFA excess yard for salvage and the remaining components were transported to the CFA landfill for disposal.

\section{Miscellaneous Radiologically Clean Items.} The cooling water pumps and motor, cooling water valves and water lines, heating system (boiler), raw water surge tank, associated piping and valves, 8 -in. stainless steel pipe, ductwork to generator, maintenance rail crane (see Figure 15), main electrical switches, small instrument panels, cable trays, and generator field rheostat (see Figure 5, Item Numbers 17-19, 25, 27, 30-32, 36, 37,39 , and 40 , respectively) were dismantled and sized as required for disposal (see Figure 16). The maintenance rail crane, main electrical switches, small instrument panels, cable trays, and the ductwork were transported to the CFA excess yard for salvage and the remaining items were disposed of at the CFA landfill.

Gland Seal Tank and System Piping. The piping to the gland seal tank was cut, sized, and packaged in a waste box with the gland seal tank (see Figure 5, Item Number 9) which was removed using a forklift with an extension boom (see Figure 17). These radiologically contaminated materials were packaged and transported to RWMC for burial.
Turbine-Generator. The turbine-generator (see Figure 5, Item Number 33) end covers and the exciter were removed during the removal of the steam turbine and transported to the CFA landfill for disposal. The electrical cables were disconnected from the generator and the rotor was pulled out of the stator (see Figure 18) to facilitate lifting of the of the two assemblies through the opening in roof of the turbine building. The stator was unbolted from the floor and broken free of the concrete by driving metal wedges between the bottom of the stator and the I-beams of the support structure. A lift fixture that was specifically designed for lifting the stator was used to lift the assembly through the roof of the building and place it on the transport vehicle. The stator (see Figure 19) and the rotor were wrapped in two layers of contamination control plastic and transported to RWMC for burial. The lift fixture could not be remotely disconnected from the stator so it also was buried at RWMC.

Condensate and Air Ejector Systems. The condensate and air ejector systems and associated piping (see Figure 5, Item Numbers 4-8, 10-12) were removed, sized, packaged in boxes, and transported to RWMC for disposal as low-level radiological waste.

Condenser Vessel. The condenser vessel (see Figure 5, Item Number 3) was blocked up using $4 \times 6$-in. timbers to prevent it from settling or moving during removal of the turbine assembly and piping that was connected to the vessel. The top section of the condenser vessel (see Figure 20) was unbolted and removed from the main vessel to reduce weight and facilitate handling of the vessel during removal operations. The top section of the condenser vessel was lifted out of the building and is being stored at the reactor building. This section of the condenser vessel will be sent to WERF for sizing to reduce waste volume and ultimately buried at RWMC. Openings in the condenser vessel were closed with plywood and caulking. The main portion of the condenser vessel was lifted out through the south wall of the turbine building (see Figure 21) and placed on a transport trailer. The vessel was wrapped in two layers of contamination control plastic and transported to RWMC for burial. 


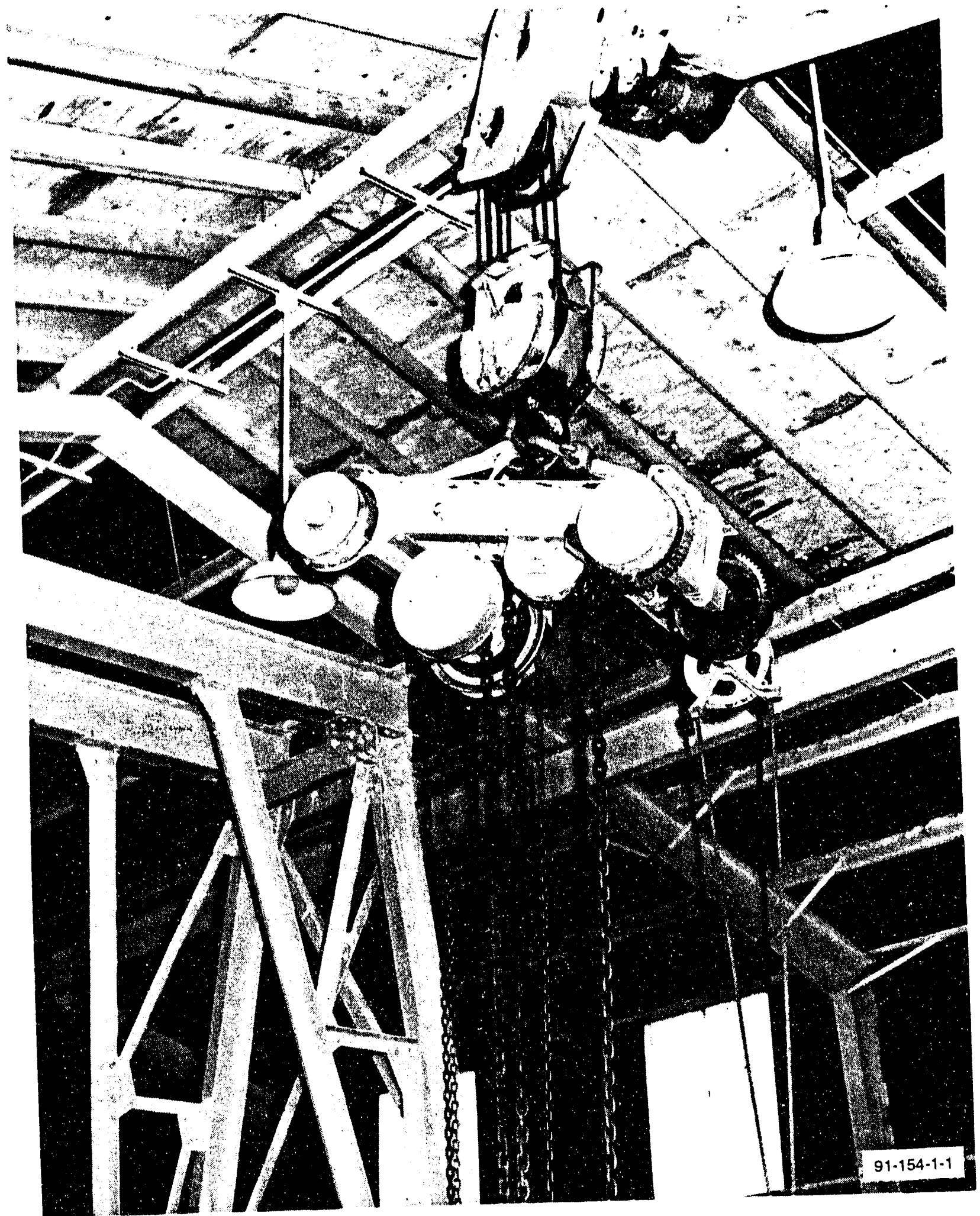

Figure 15. Disassembly of the 10-ton maintenance rail crane. 


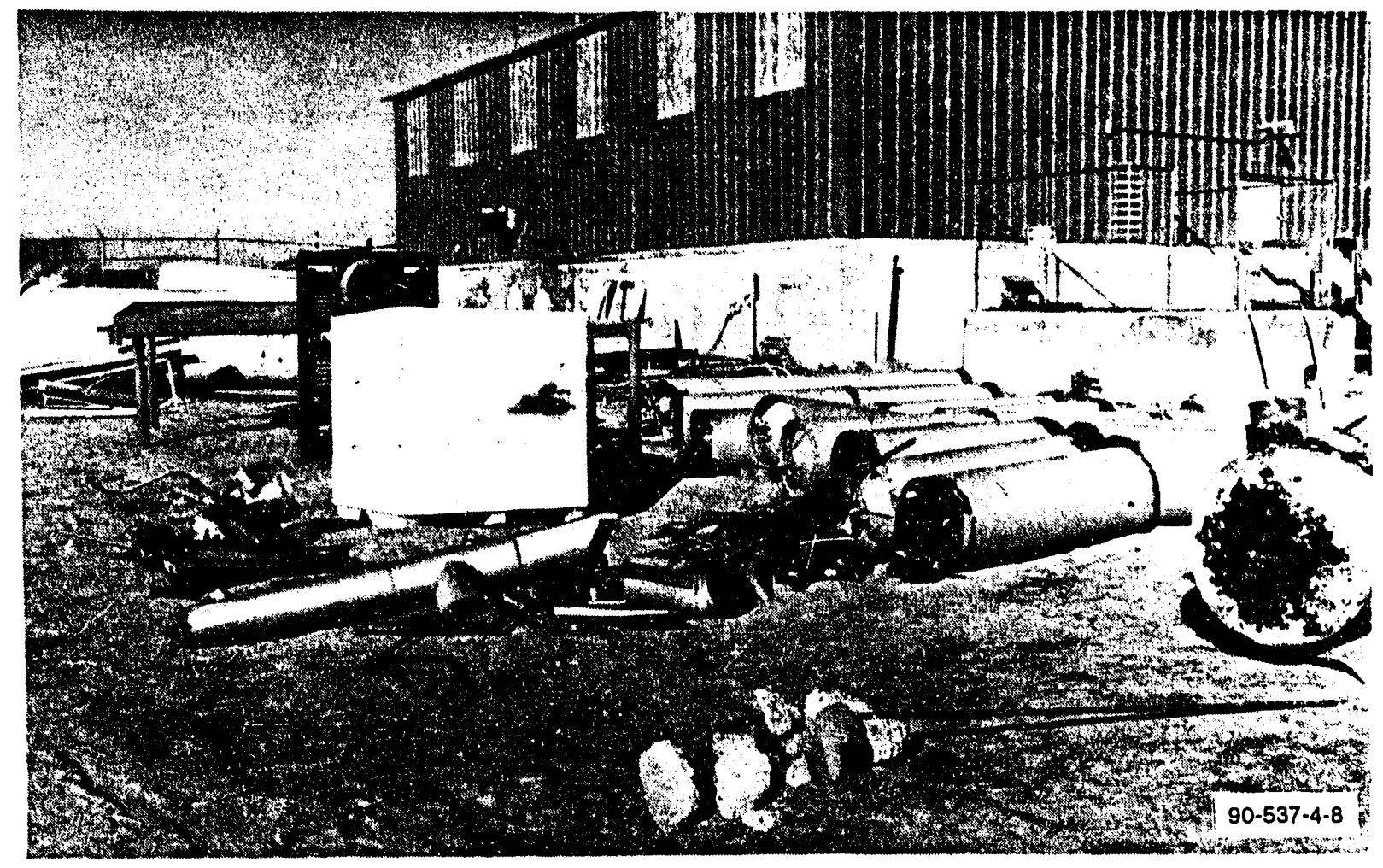

Figure 16. View of a portion of the radiologically clean equipment removed from turbine building. 


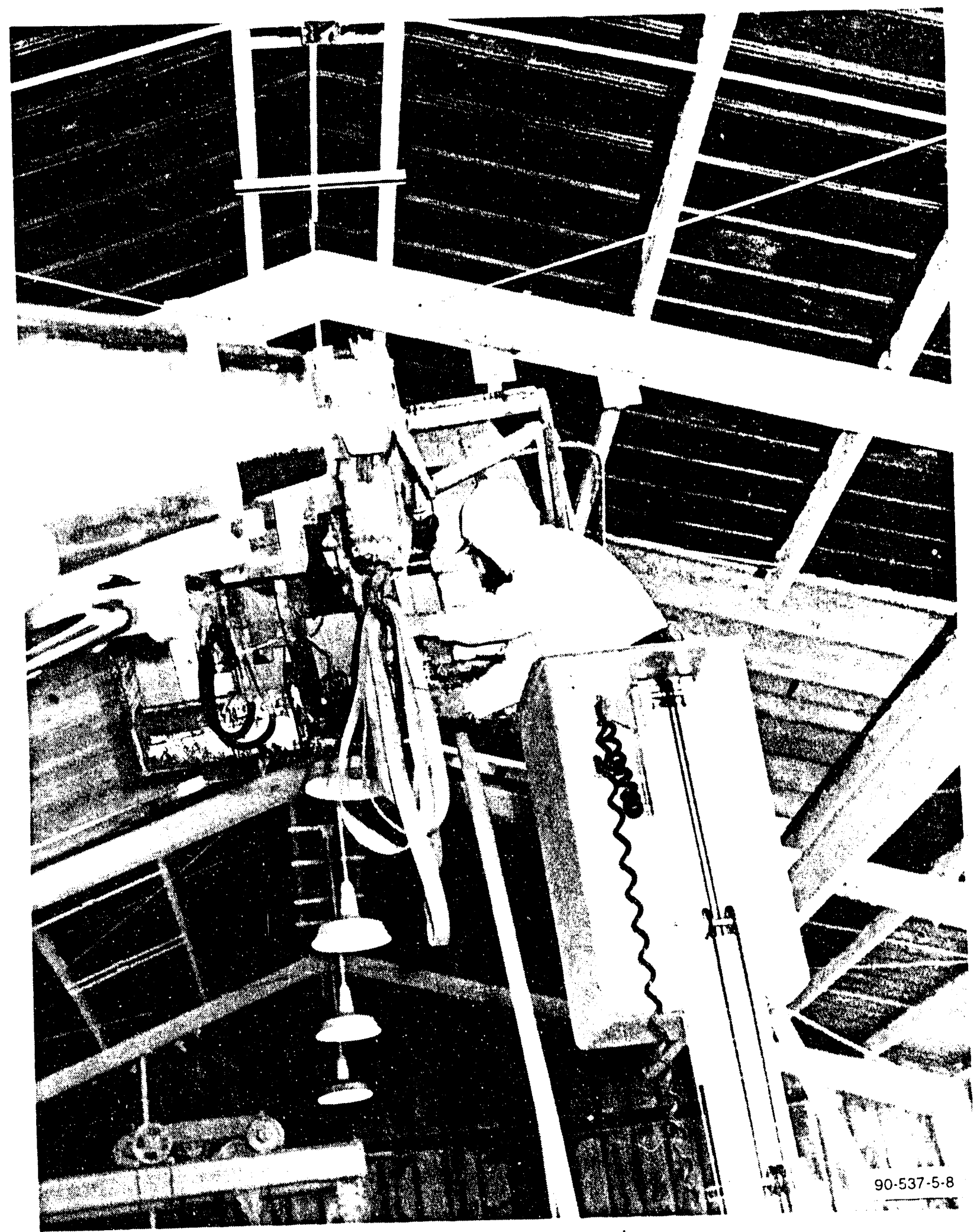

Figure 17. Preparation for removal of the gland seal water tank. 


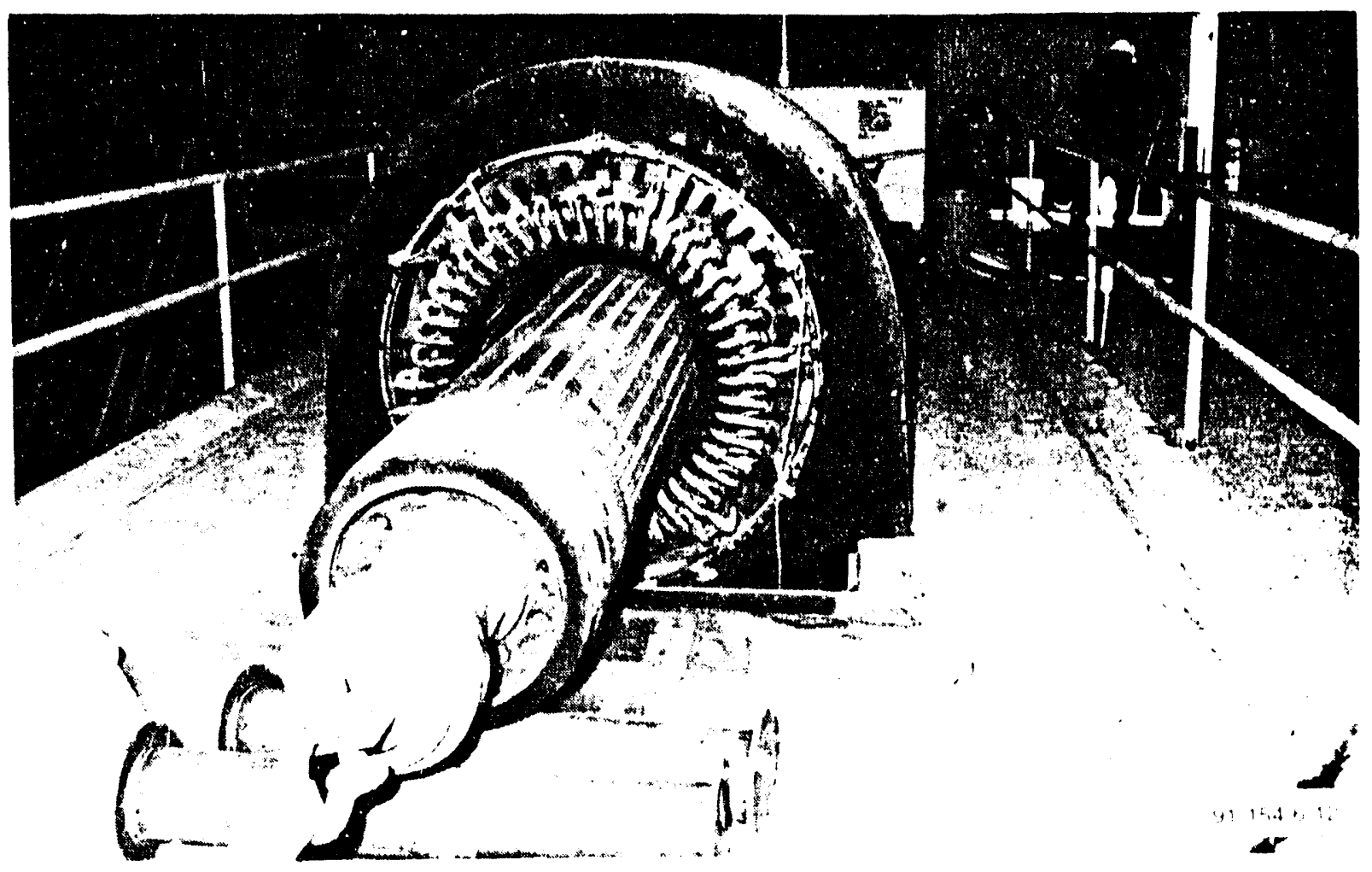

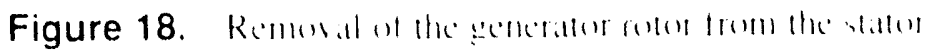

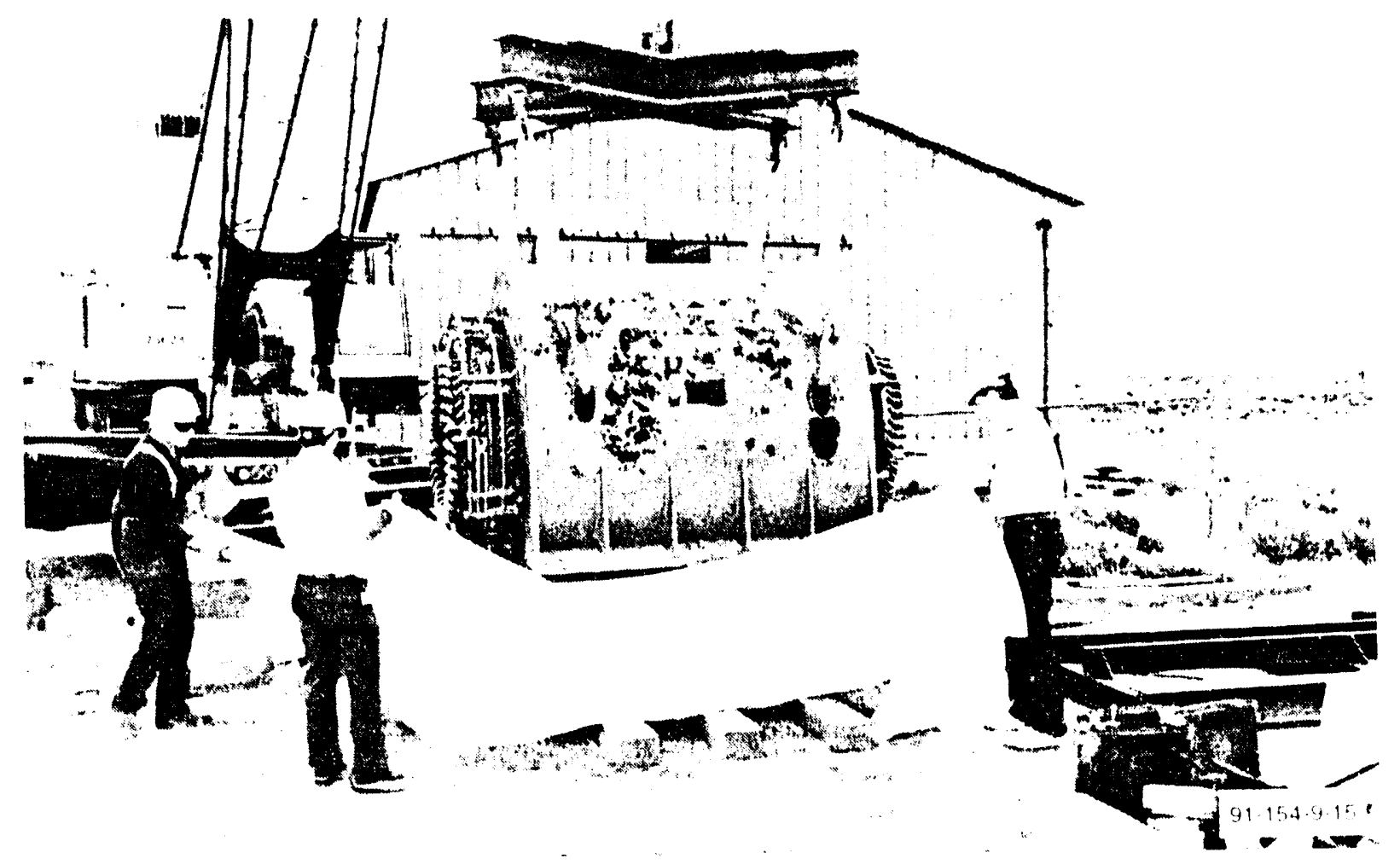

Figure 19. Preparation of the generater stator for shapment to RWM. 


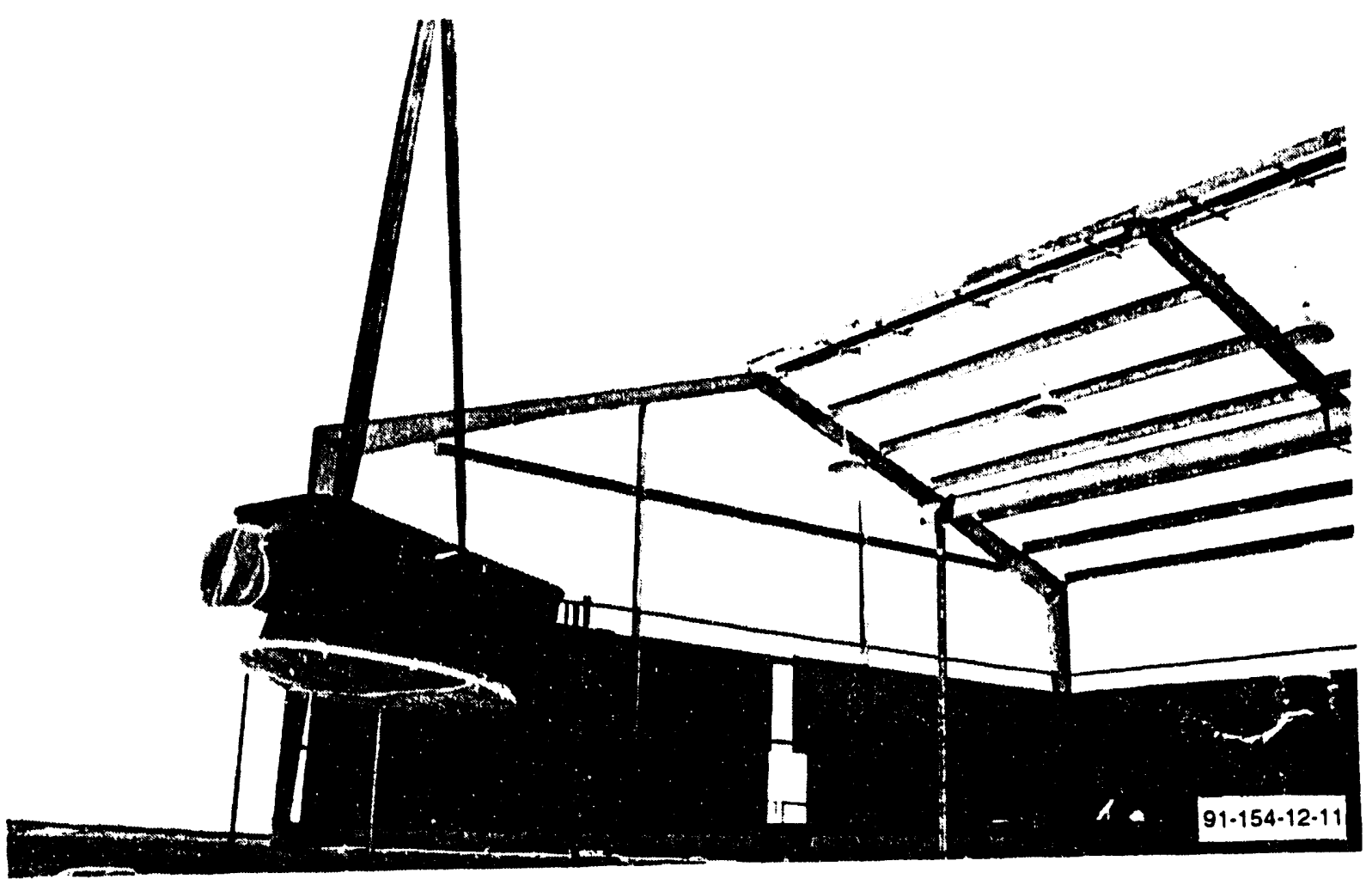

Figure 20. Removal of the upper section of the condenser vessel from turbine building.

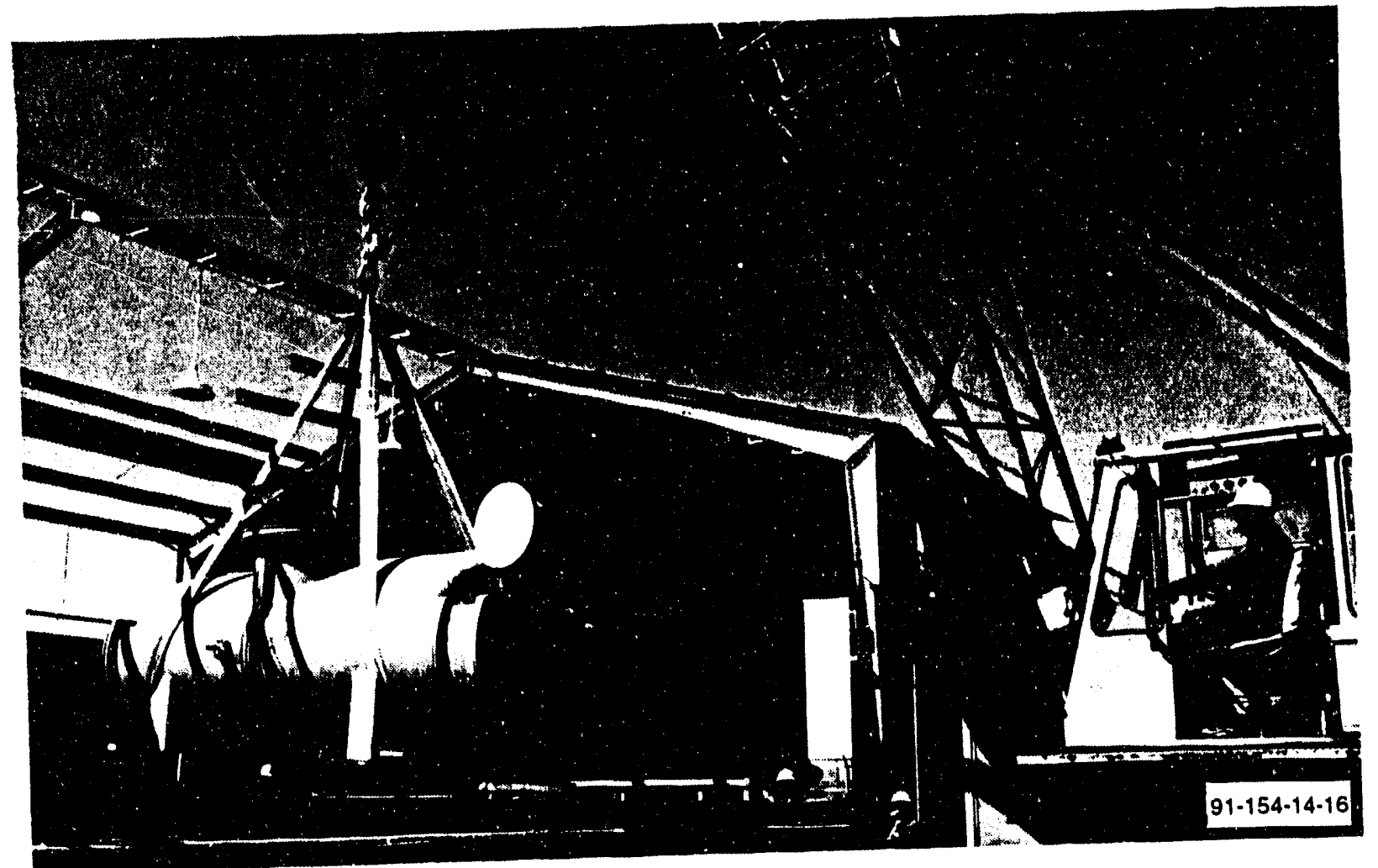

Figure 21. Removal of the 15-ton condenser vessel from turbine building. 
Turbine-Generator Support Structure. Jackhammers were used to break up the 4- to 6-in. uncontaminated concrete slab poured on the top of the support structure steel substructure. The concrete was boxed and removed from the building basement to be used later for fill material during the demolition and backfill of the basement. The support structure steel I-beams were cut with acetylene torches into manageable sizes and removed from the turbine building with a mobile crane (see Figure 22). The steel from the support structure was transported to the CFA Property Management excess yard for salvage.

Turbine Building Metal Structure. The sheet metal roofing and siding was removed to provide access to structure metal framework. Acetylene torches and electric saws were used to aid in the dismantlement of the uncontaminated building structure. The building metal framework and roof were removed in sections (see Figures 23 and 24) and sized as required for loading onto vehicles for transport to the CFA Property Management excess yard for salvage.
Turbine Building Foundation Demolition. Radiological surveys were performed on the interior and exterior of the building foundation upon completion of the equipment removal operations. Figures 25 and 26 provide views of the turbine building foundation and basement prior to demolition. The areas found to have fixed contamination above releasable limits were decontaminated using surface intrusion methods such as chipping and use of an air-driven needle gun.

Upon receipt of the verification statement for the turbine building ${ }^{17}$ from the Independent Verification Contractor (IVC), demolition of the concrete foundation with explosives to $6 \mathrm{ft}$ below grade was performed using an approved demolition plan. ${ }^{18}$ The method of demolition followed techniques previously used at the INEL which provided safe and inexpensive demolition of concrete foundations. Welders cut rebar that did not shear from the detonations and a bulldozer was used to push larger sections of the broken concrete into the basement of the building for burial.

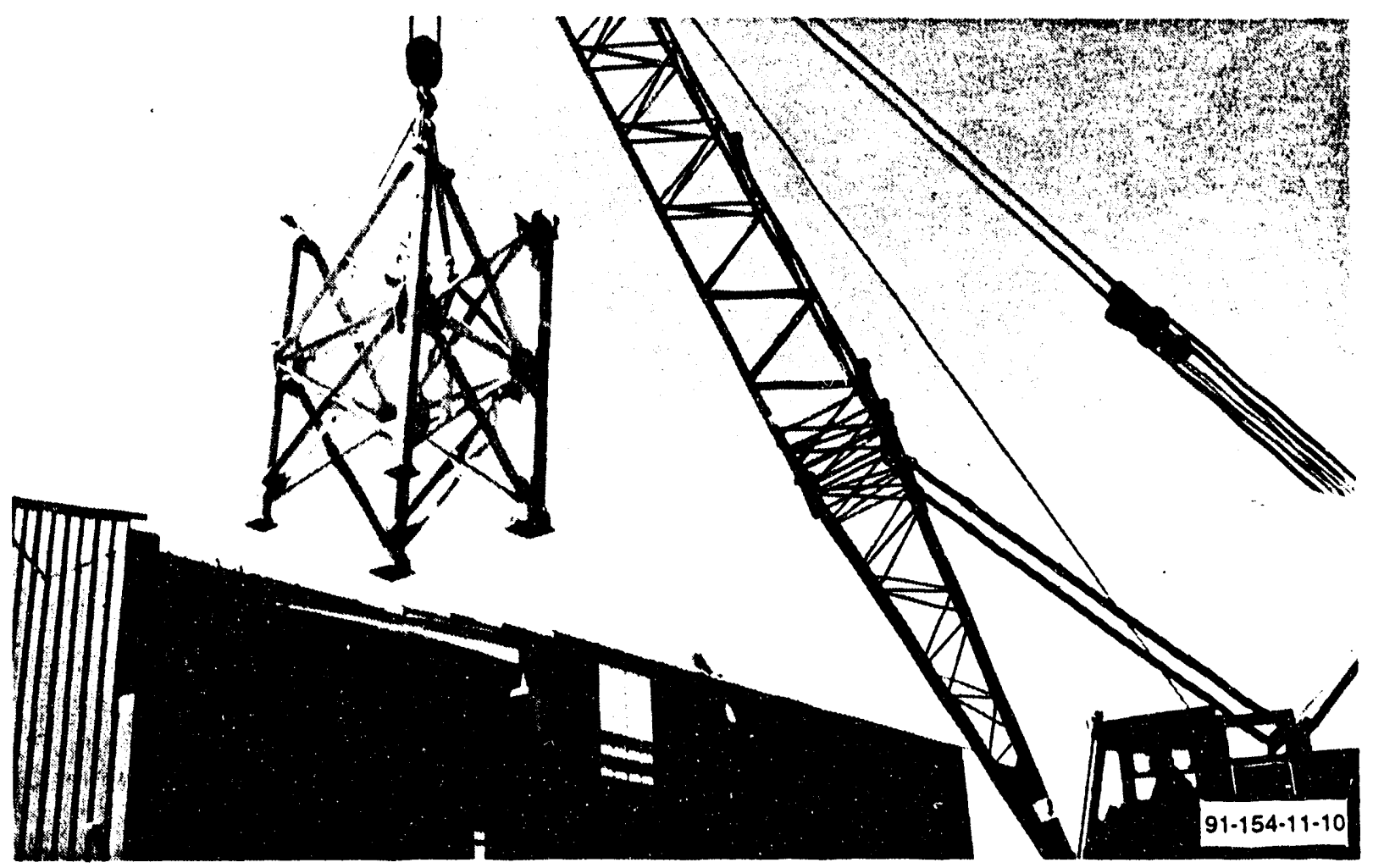

Figure 22. Removal of a section of the turbine-generator steel support structure from the turbine building. 


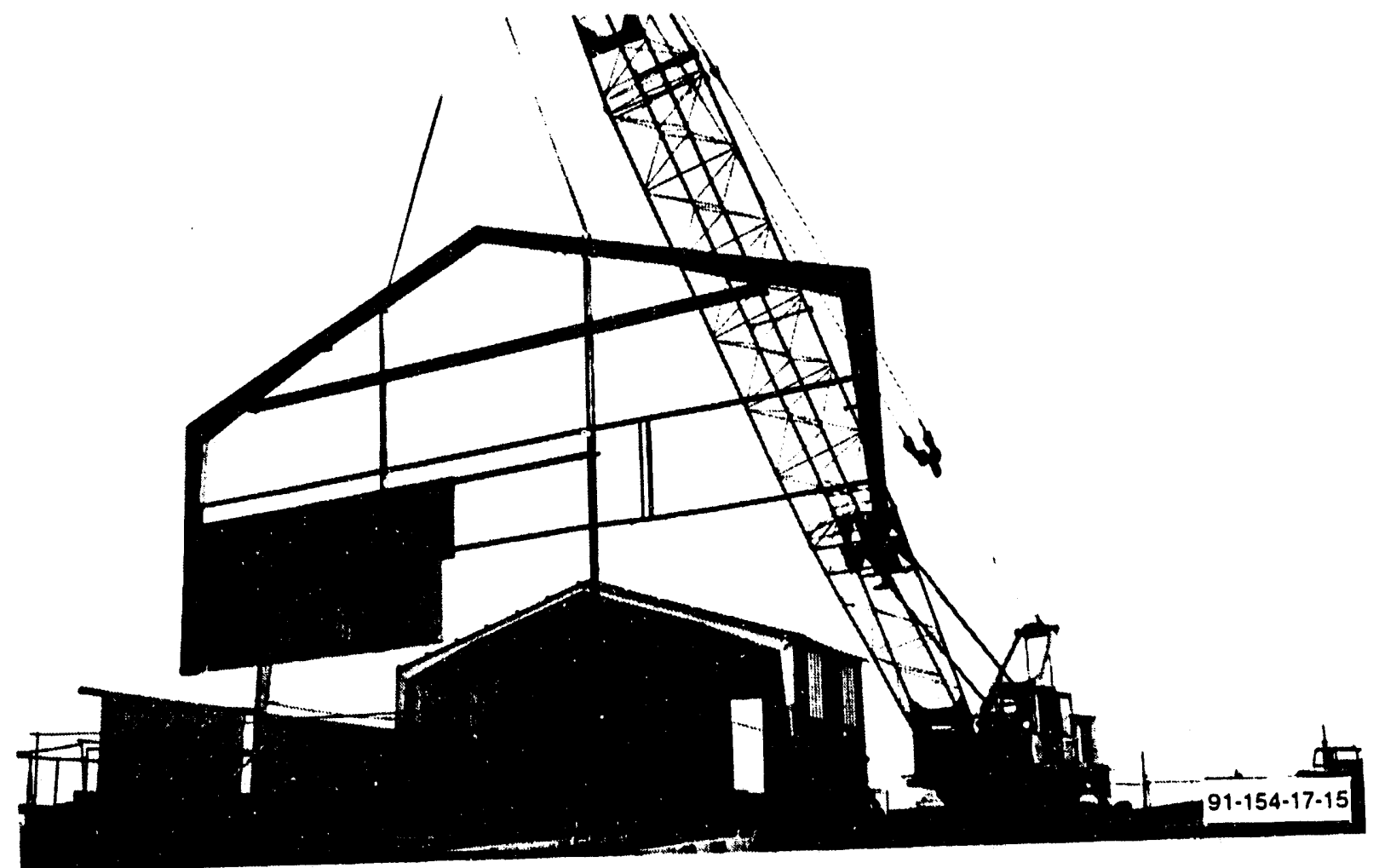

Figure 23. Removal of a portion of turbine building metal framework.

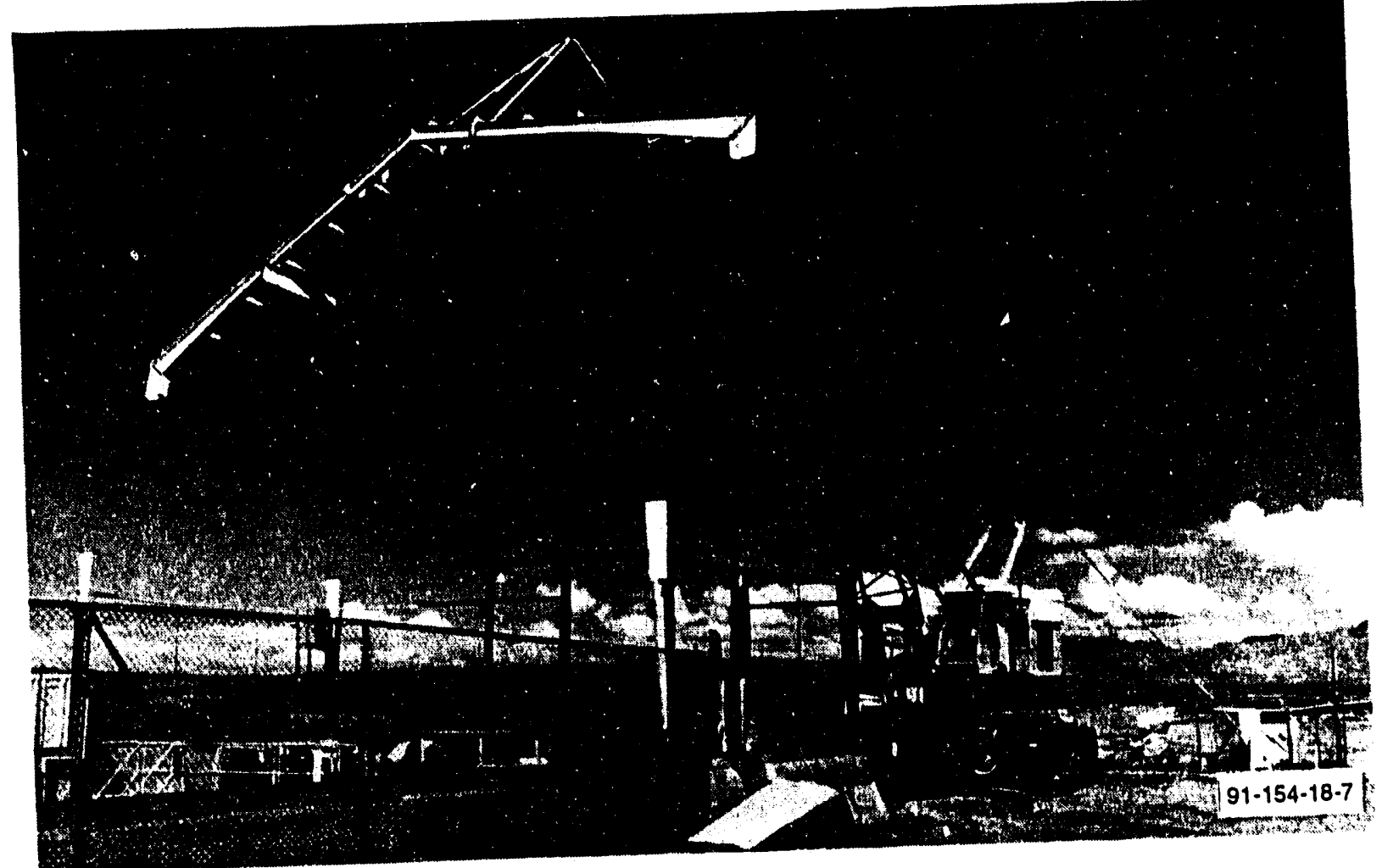

Figure 24. Removal of a portion of the turbine building roof. 


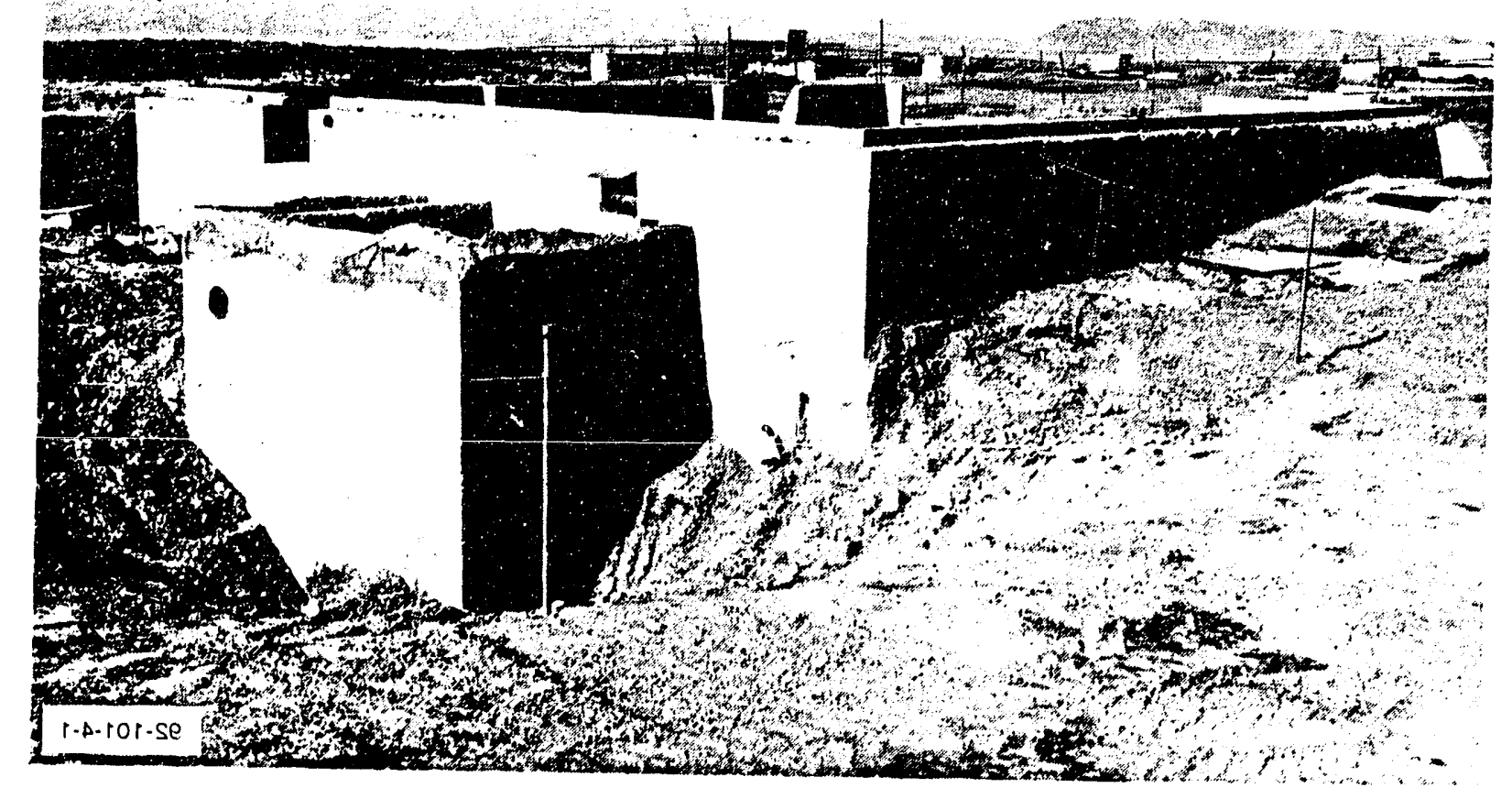

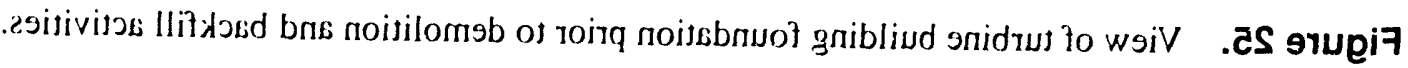

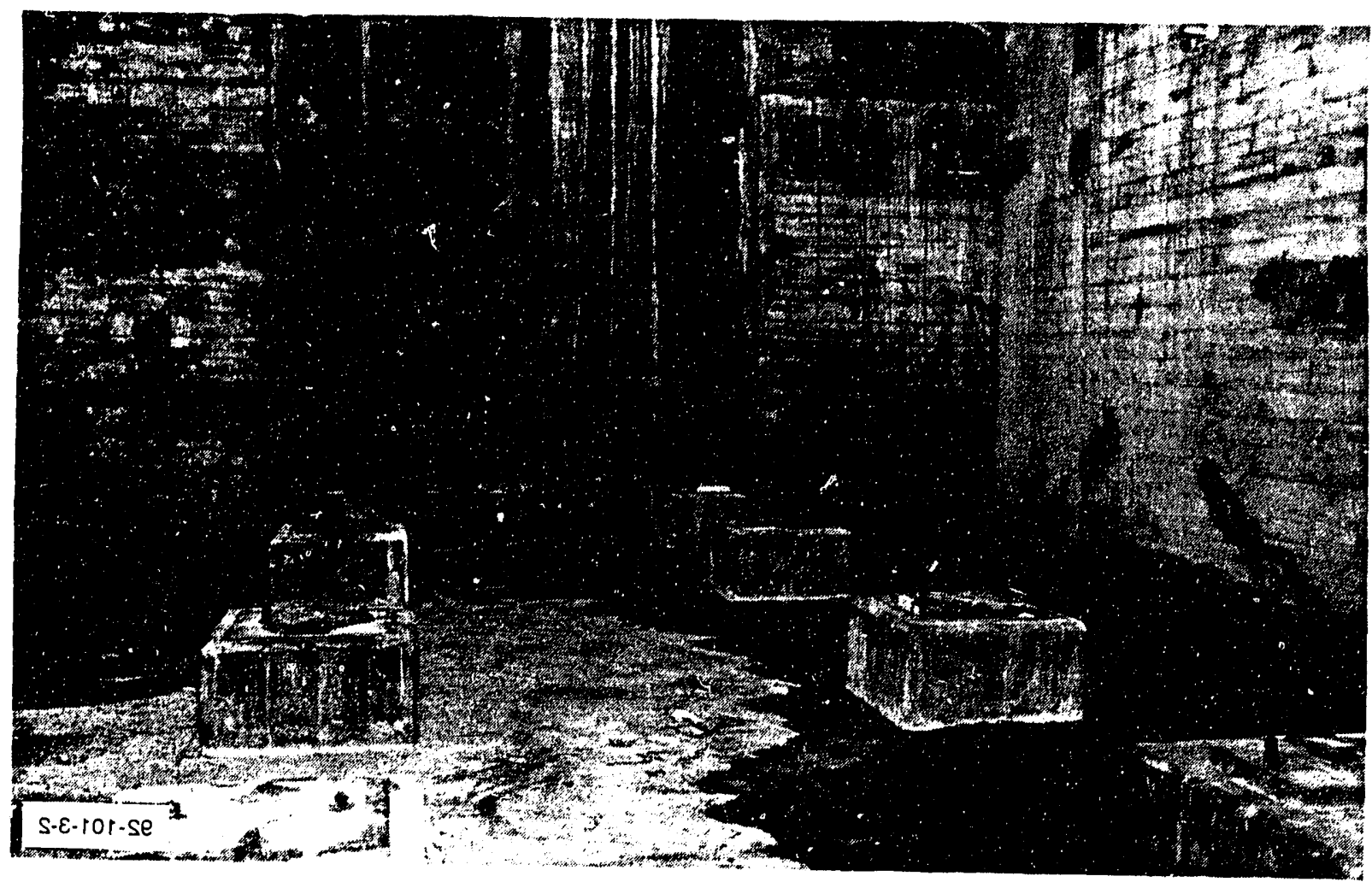

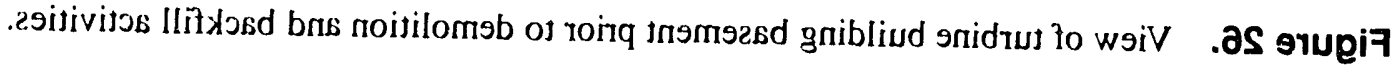


Figures 27 through 31 provide views of the turbine building foundation during the demolition activities.

Turbine Building Foundation Backfill. Fill material was transported to the BORAX-V site from a pit approximately two miles north of the facility. A front-end loader was used to push the fill material into the basement and craters left by the detonations. A grader was used to contour the building foundation area to match the surrounding area. Figure ?2 shows the turbine building area at completion of the backfill activities.

Underground Storage Tanks (UST). Three tanks were removed under an $\mathrm{MTF}^{19}$ for the UST Program. Two USTs were removed from the southwest corner of the turbine building foundation and an additional UST from the west side of the reactor building in the fall of 1990 by the UST Program personnel. The three USTs were transported to the tank storage yard at CFA, cut up, and disposed of at the CFA landfill. These three UST locations were registered as Consent Order and Compliance Agreement sites and details can be found under the UST Program Tank Removal Summaries for BORAX-5 and BORAX-7.

Waste Water Line. Approximately $75 \mathrm{ft}$ of 8 -in. diameter contaminated corrugated metal piping was excavated from the west side of the turbine building. The piping was sleeved, cut into sections, and packaged in waste boxes. A small amount of contaminated soil found under sections of the piping that had rusted through was also cleaned up and packaged in waste boxes. Samples were collected and analyzed for radiological contaminants from the excavated area to ensure that all of the contaminated soil was removed. This piping was a portion of the piping that carried waste water to the leach pond from the reactor and turbine buildings.

Marker Placement. The D\&D permanent marker depicting the burial site of the turbine building basement will be placed upon completion of the reactor building D\&D. The location for the marker has been surveyed and recorded.

\section{Post-Decommissioning Radiological Survey}

Upon completion of the turbine building D\&D work, except for demolition and backfill of the foundation, a radiological survey of the foundation exterior and interior surfaces was performed by EG\&G Idaho HPs in October 1991. The HPs used a Geiger/Mueller (GM) tube detector for direct scan contamination readings and ion chamber instrument for beta-gamma radiation measurements. Results of the survey indicated that the only areas remaining with fixed contamination was in the basement sump pump pit and trench, and an area on the basement floor approximately $1 \mathrm{~m}^{2}$. Smears were collected from these areas and counted on an alpha/beta-gamma scaler. All smearable contamination was $<200 \mathrm{dpm} / 100 \mathrm{~cm}^{2}$ beta-gamma and no alpha contamination was detected.

The D\&D Plan was written to meet radiological release criteria established in Development of Criteria for Release of Idaho National Engineering Laboratory Sites Following Decontamination and Decommissioning. ${ }^{20}$ Starting in November of 1990 DOE also required verification of the radiological survey by the INEL IVC, Oak Ridge National Laboratory, Grand Junction (ORNL-GJ), Pollutant Assessments Group (PAG) to confirm the site's compliance with DOE guidelines for unrestricted release. ${ }^{21,22}$ The verification included reviews of the BORAX-V D\&D Plan and data provided in the pre- and post-remedial action surveys. ORNL-GJ conducted the survey on November 20-27 and December 9-15, 1991. The survey included alpha, beta-gamma, and gamma scans; smears for detecting removable contamination; and direct measurements for alpha and betagamma activity on the basement, mezzanine floors, and the building's interior and exterior walls. The building walls and floors were divided into grids to assist in the surveys. In addition, soil samples were collected and analyzed from random locations near the building perimeter. Instruments used included thin-window GM detectors for alpha and beta measurements, gas proportional beta-gamma detector, and a gamma scintillator 


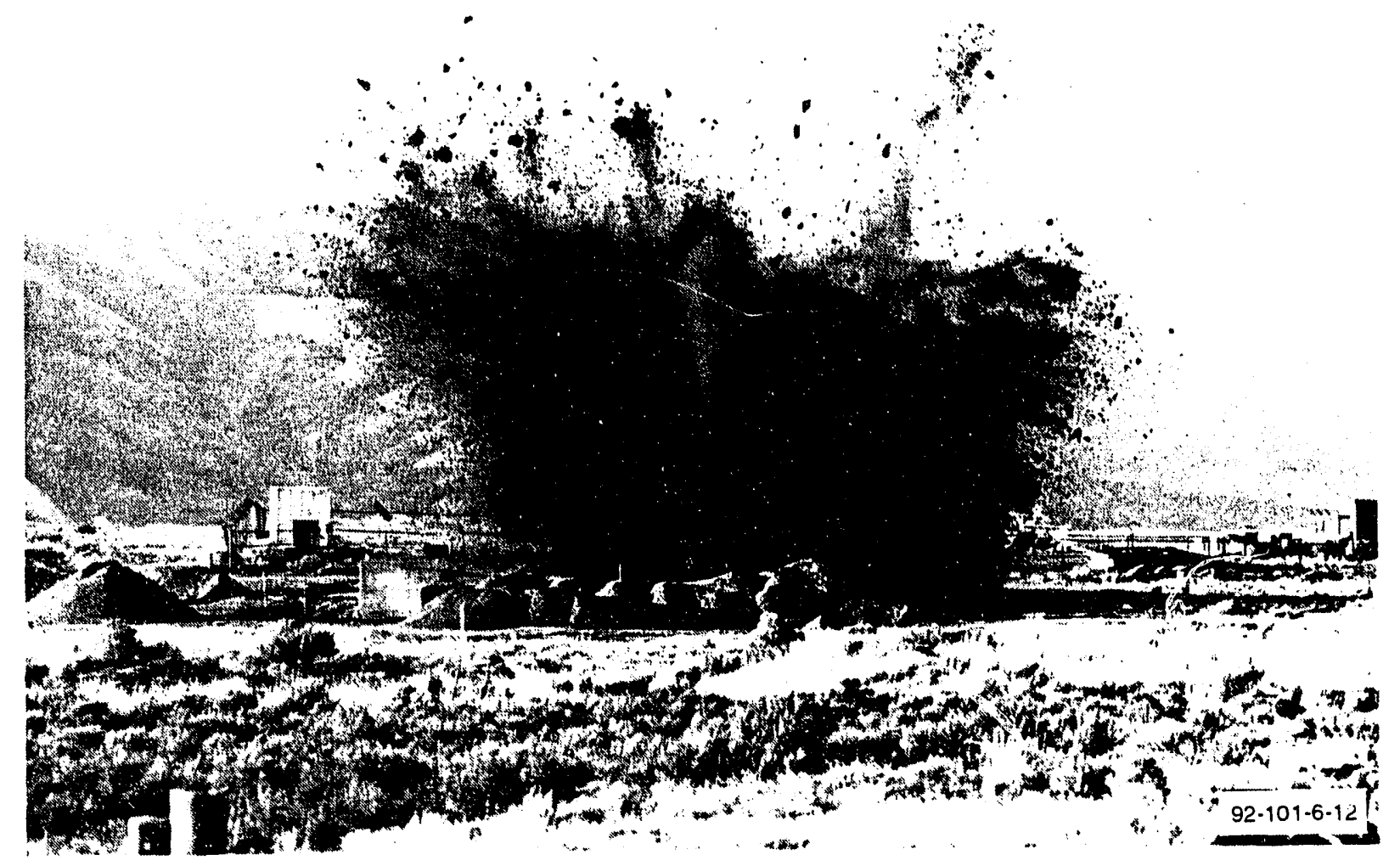

Figure 27. View of demolition of turbine building east wall.

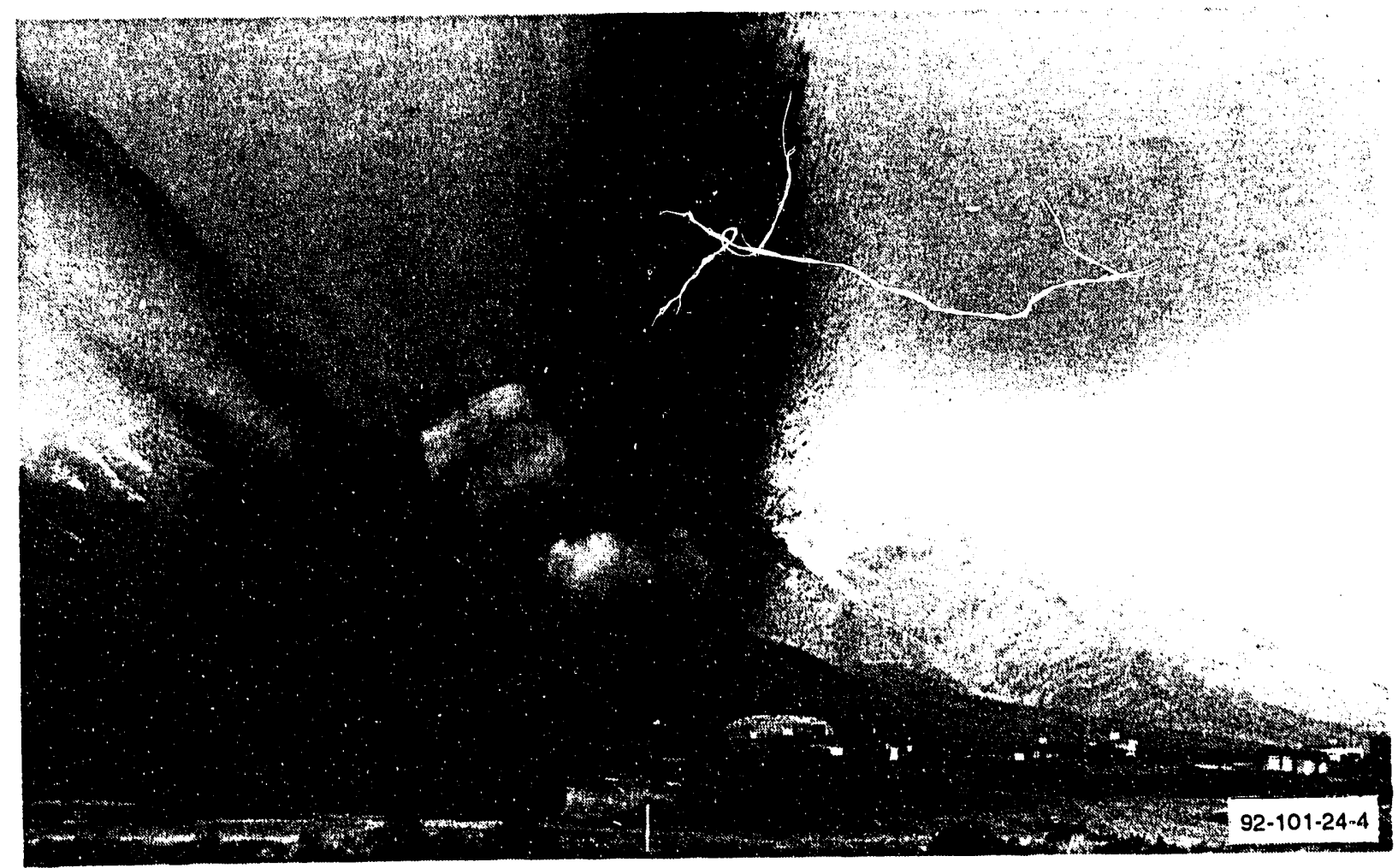

Figure 28. View of demolition of turbine building west wall. 


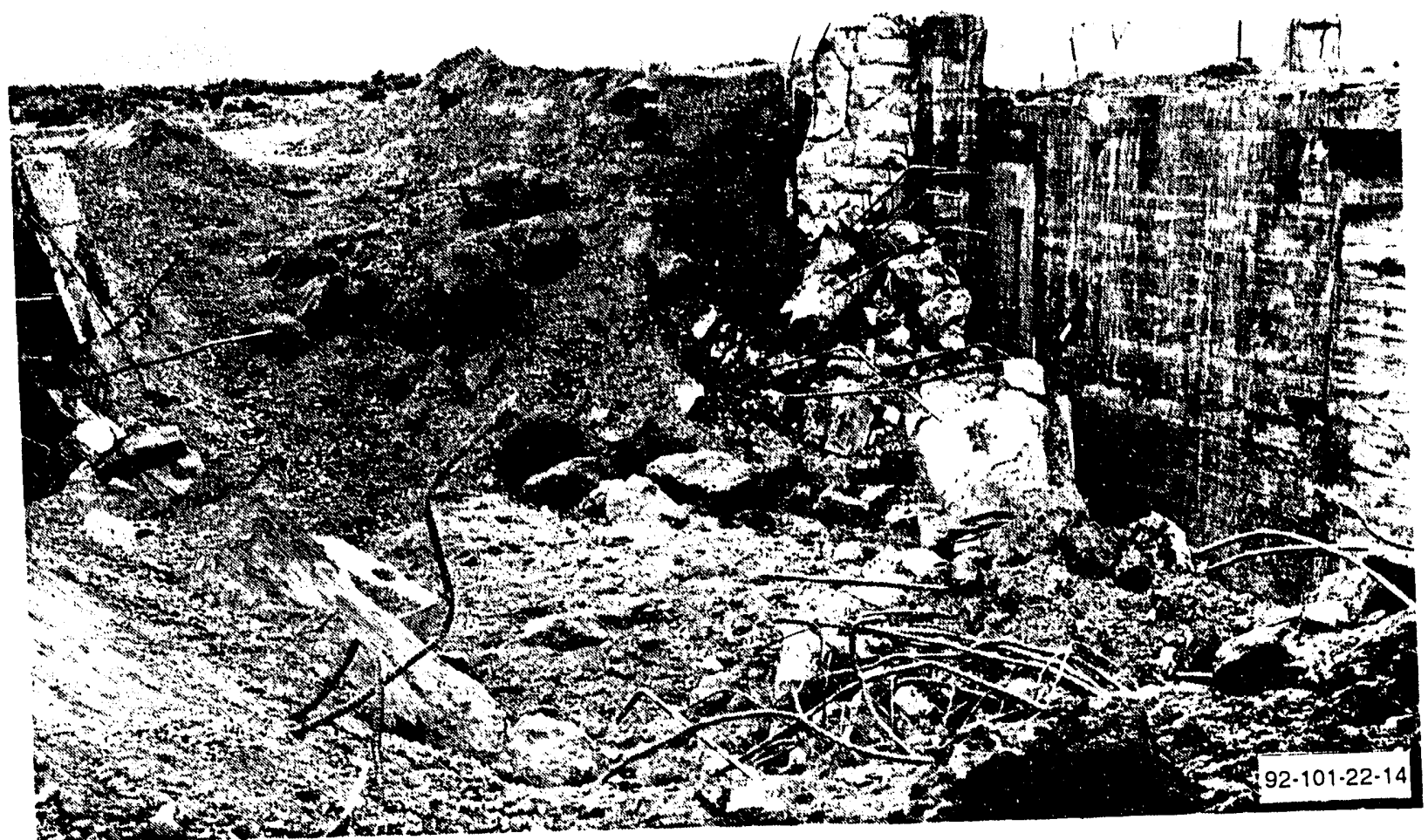

Figure 29. View of turbine building foundation after demolition of east, west, and south walls.

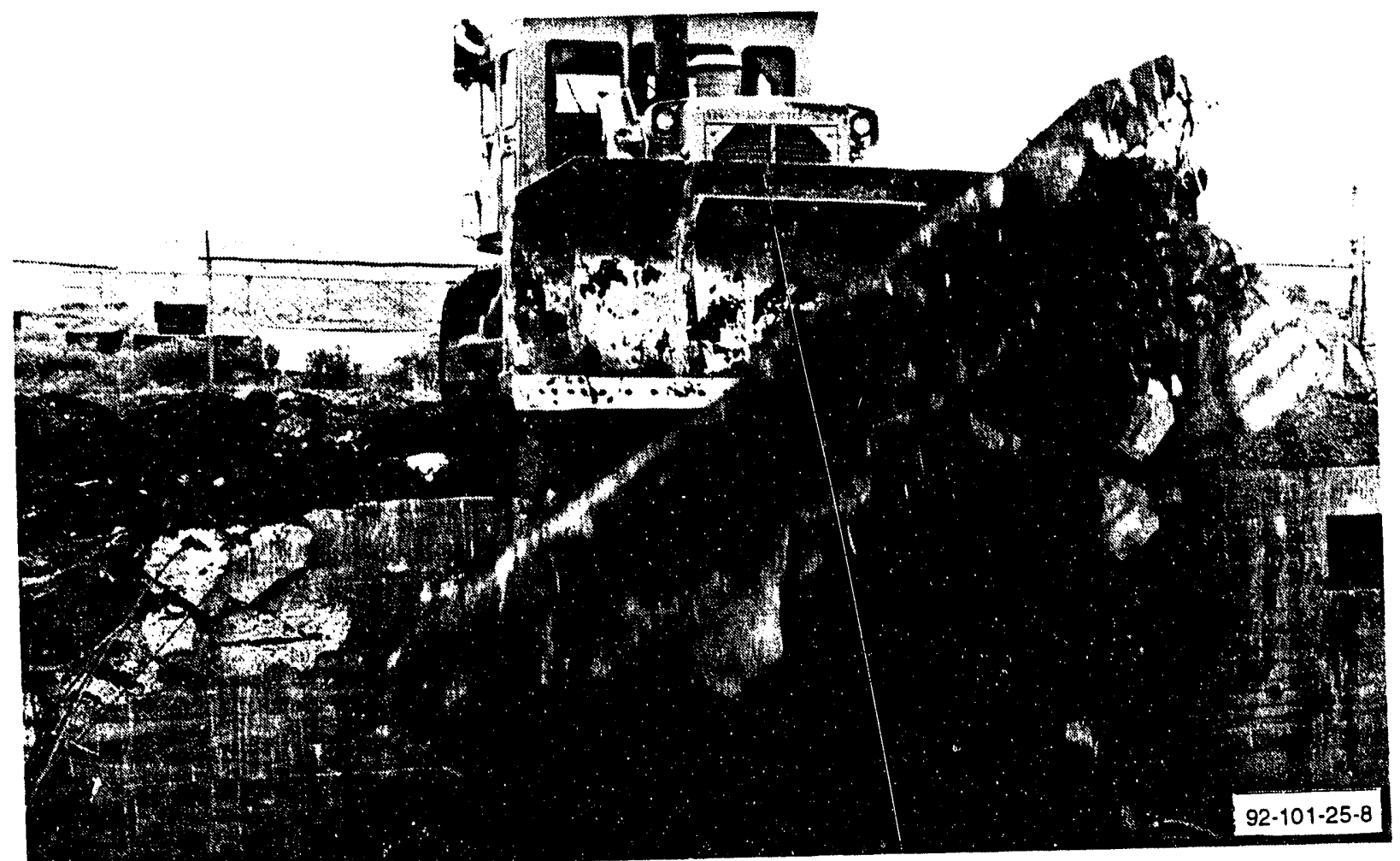

Figure 30. View of bulldozer completing breakup of turbine building main floor concrete. 


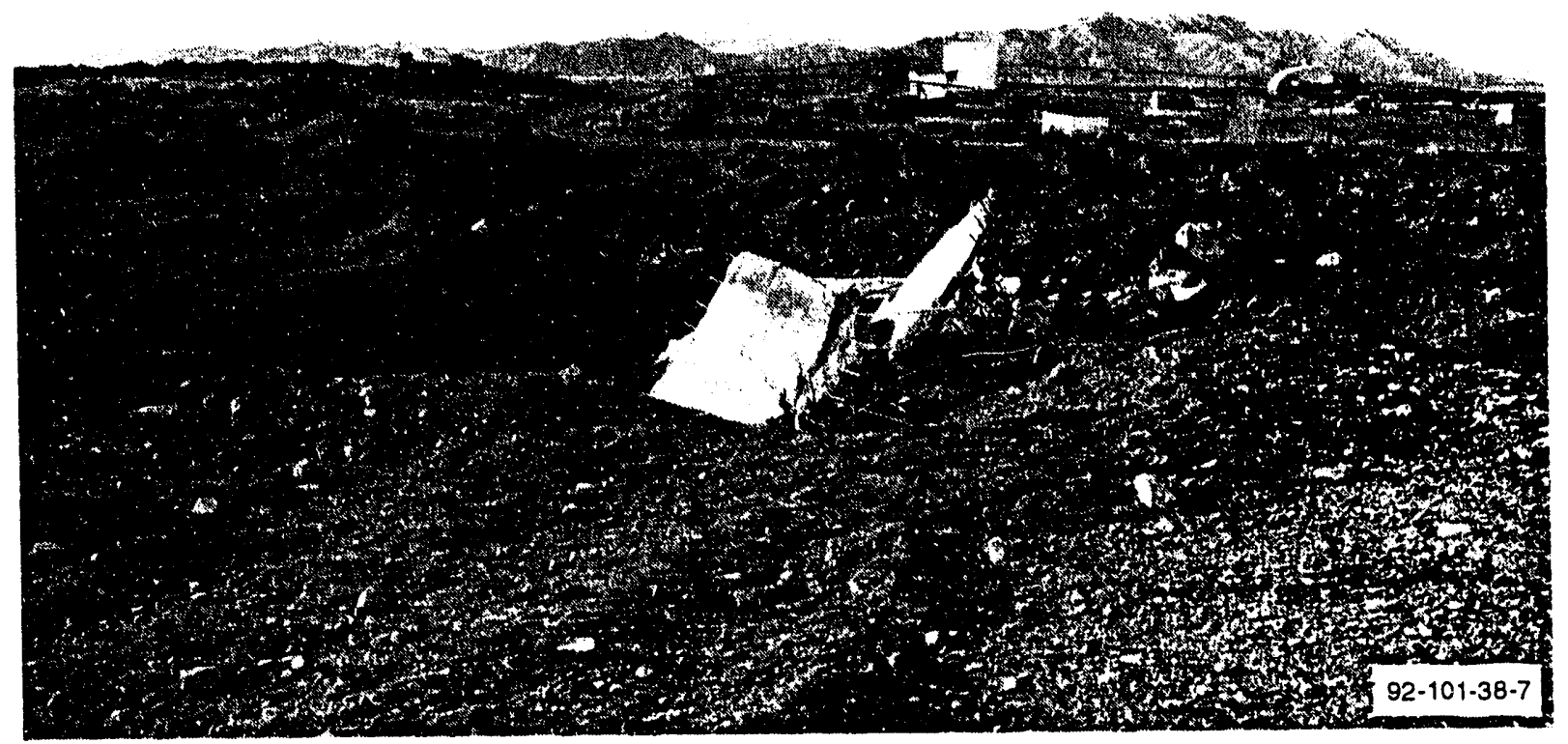

Figure 31. View of remaining pieces of concrete foundation prior to completion of backfilling turbine building site.

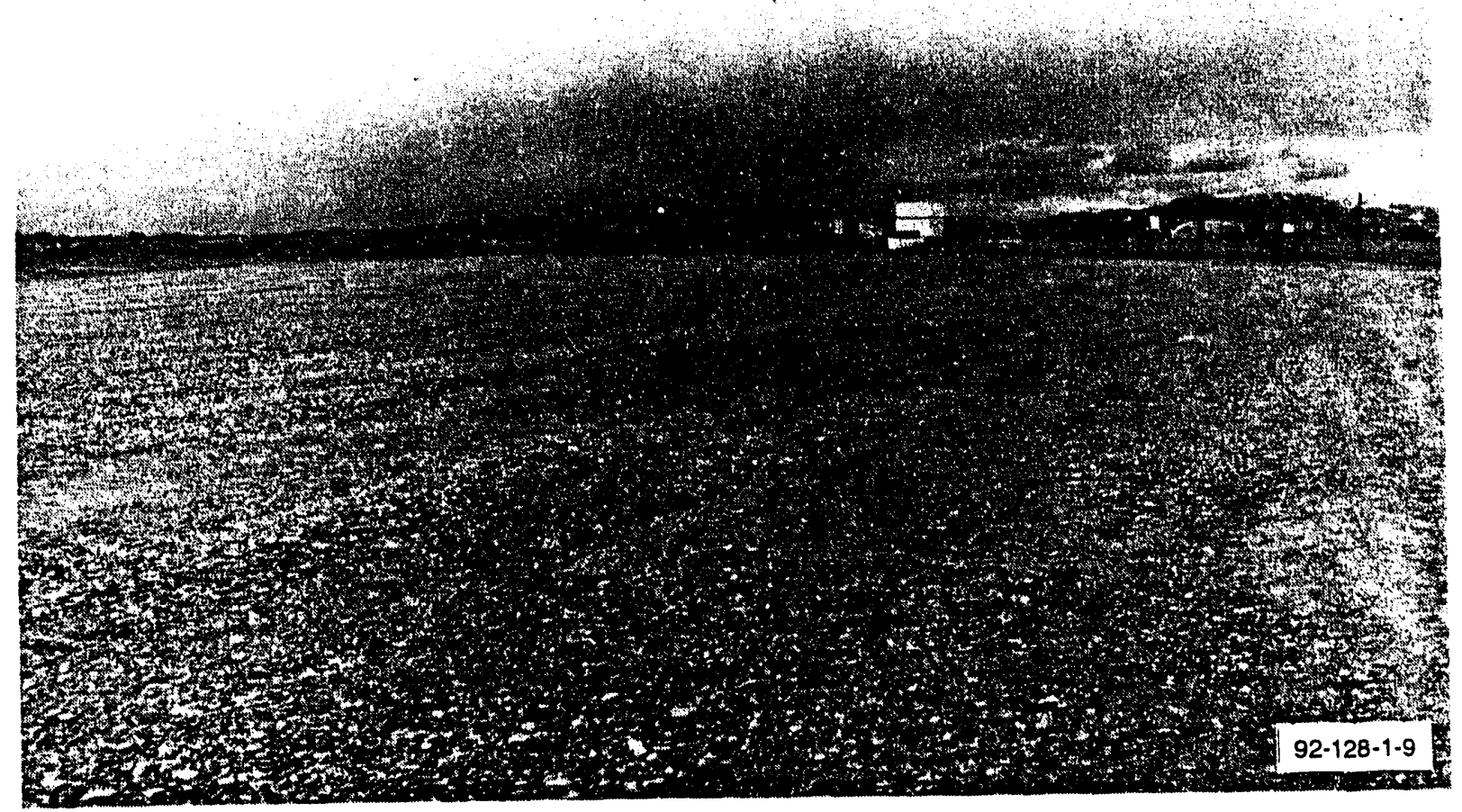

Figure 32. View of turbine building site at completion of backfilling and contouring. 
detector. The smears were counted on an alpha/ beta counter for gross activity and the soil samples were counted on a germanium lithium counter. The independent soil analysis showed no Co-60 above detection limits and the highest analysis result for Cs- 137 was $4.6 \mathrm{pCi} / \mathrm{g}$ which is below the site specific guideline of $10 \mathrm{pCi} / \mathrm{g}$. The soil sample results show that the area is radiologically clean, with only naturally occurring radionuclides present in quantities typical of background levels found in this area.

Two areas in the sump pit trench and the area on the basement floor that was found to be contaminated during the EG\&G Idaho survey were found to have levels of contamination above the releasable limits. These areas were remediated and a report transmitted from EG\&G Idaho to the IVC through DOE-ID. ORNL-GJ reviewed the report and agreed the remediation was effective in removing the source of the elevated direct radiation. Therefore, the turbine building site met the requirements established for unrestricted release for subsequent use, which conforms to the guidelines outlined in References 20 and 21 .

\section{Post-Decommissioning Hazardous Chemical Surveys}

Hazardous chemical surveys were not performed at the completion of the equipment and building D\&D activities as previous sampling proved the absence of hazardous constituents.

The only hazardous waste encountered during the $D \& D$ activities was mercury contained in some of the facility instrumentation and some debris contaminated with mercury from a spill. The area of the spill was contained in a concrete cable trench on the main floor of the building. The debris in the trench was cleaned up and packaged under the direction of an IH. HP survey of the debris and instruments containing mercury showed absence of any radiological contamination. This hazardous waste was transported to the HWSF at CFA and later disposed of by an outside contractor having a RCRA treatment, storage, and/or disposal permit. 


\section{COST AND SCHEDULE}

The major D\&D activities on the turbine building started in FY-89 and were completed in FY-92. The scheduled completion date for the turbine building in the 1990 revision of the D\&D Plan was September 1990. Due to delays in preparation and approval of project and NEPA documentation, the major portion of the D\&D activities did not start until October 1990. The estimated costs to complete D\&D of the turbine building in the 1990 D\&D Plan are shown in Table 3 along with the actual costs. The total cost for D\&D of the turbine building excluding costs prior to FY-89 were as follows:

FY-89

$\begin{array}{lll}\text { FY-90 } & -\end{array}$

$\begin{array}{lll}\text { FY-91 } & - & \$ 465 \mathrm{~K} \\ \text { FY-92 } & - & \$ 167 \mathrm{~K} \\ \text { Total cost } & - & \$ 1,528 \mathrm{~K}\end{array}$

The total actual costs were $\$ 363 \mathrm{~K}$ above the estimated costs to complete the turbine building in 1990 . The major contributors to these additional costs were additional project support/ management costs due the increased length of the project, increased project planning costs, increase in cost of performing the D\&D activities, and performing added workscope of $\$ 100 \mathrm{~K}$.

Figure 33 shows a schedule summary of the activities performed for the D\&D of the turbine building.

Table 3. Detailed cost breakdown

\begin{tabular}{lcc}
\hline \multicolumn{1}{c}{ Major components of effort } & $\begin{array}{c}\text { Estimated cost } \\
(\$ K)\end{array}$ & $\begin{array}{c}\text { Actual cost } \\
(\$ K)\end{array}$ \\
\hline Project Support/Project Management & $\$ 152$ & $\$ 247$ \\
Project Planning & $\$ 47$ & $\$ 88$ \\
D\&D Operations/Final Report for Turbine Building & $\underline{\$ 494}$ & $\$ 721$ \\
Total & $\$ 693$ & $\$ 1,056$ \\
\hline
\end{tabular}




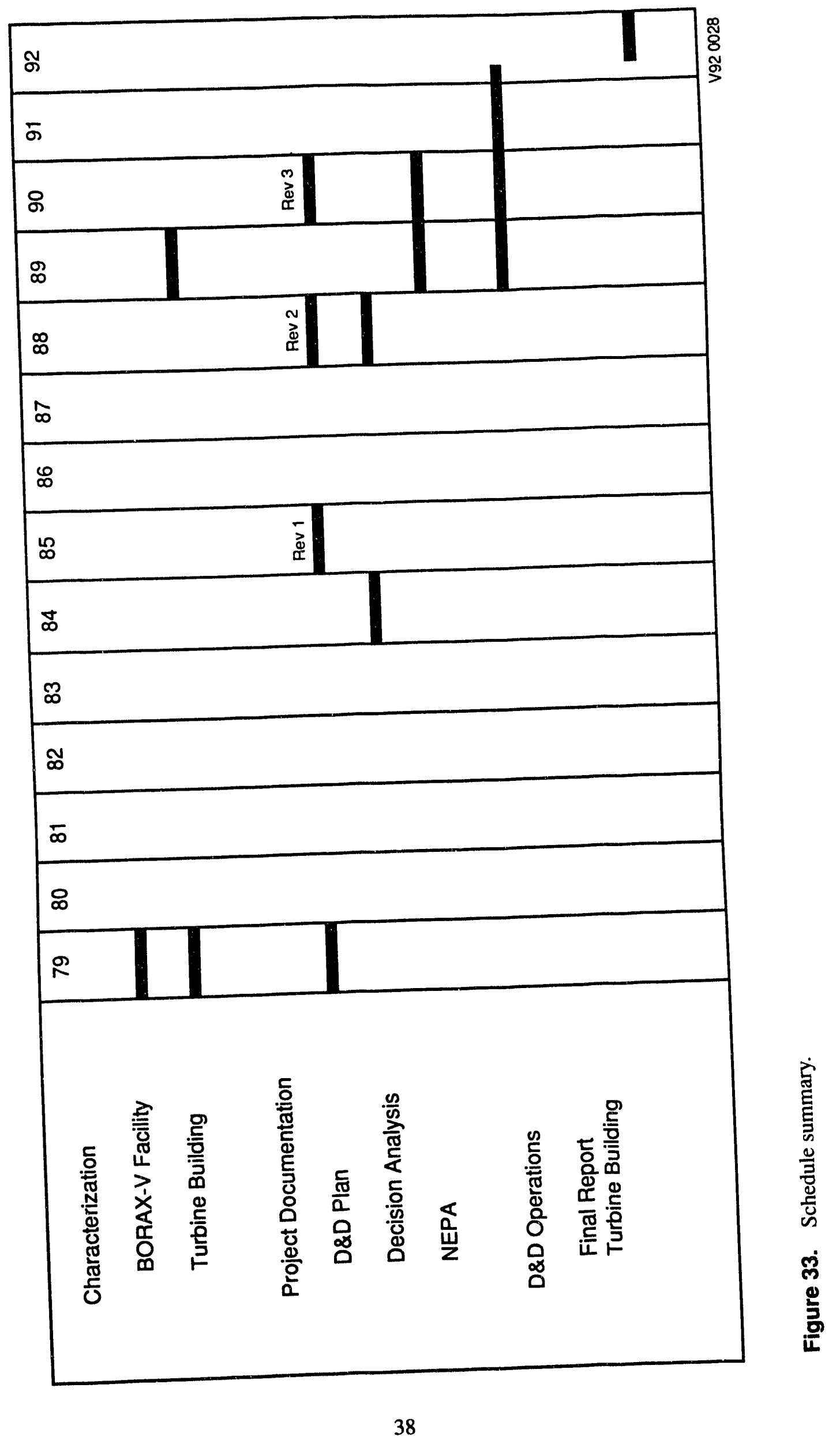




\section{VOLUME OF WASTE GENERATED}

The types of waste generated during D\&D of the turbine building included industrial (clean) waste, low-level radioactive waste, and hazardous waste. Table 4 shows the estimated waste volumes, the actual waste volumes, source and disposal location of each of these waste types.

Radioactive low-level waste disposed of at RWMC weighed approximately 117 tons and was approximately $3,000 \mathrm{ft}^{3}$ in volume. An estimated 1.63 tons of contaminated wood with a volume of $192 \mathrm{ft}^{3}$ was sent to WERF for incineration. Approximately 11 tons $\left(839 \mathrm{ft}^{3}\right)$ of waste not suitable for salvage went to the CFA landfill for disposal. The CFA excess yard was sent approximately 34 tons $\left(594 \mathrm{ft}^{3}\right)$ of materials for salvage. The HWSF received $3.3 \mathrm{ft}^{3}$ of waste containing mercury.

Table 4. Turbine building D\&D waste volumes.

\begin{tabular}{lccc} 
& $\begin{array}{c}\text { Estimated } \\
\text { volume } \\
\left(\mathrm{ft}^{3}\right)\end{array}$ & $\begin{array}{c}\text { Actual } \\
\text { volume } \\
\left(\mathrm{ft}^{3}\right)\end{array}$ & Disposition \\
\hline
\end{tabular}

Radioactively contaminated

Carbon steel:

Piping and pumps

$\begin{array}{lll}900 & 852 & \text { RWMC } \\ 115 & 120 & \text { RWMC } \\ 180 & 492 & \text { RWMC } \\ 432 & 432 & \text { RWMC } \\ 137 & 137 & \text { RWMC } \\ 904 & 206 & \text { RWMC } \\ \text { NE } & 154 & \text { RWMC }\end{array}$

Stainless steel:

Steam turbine

NE 50

Concrete:

RWMC

RWMC

Asbestos and asbestos covered piping:

Buried in place

Miscellaneous:

RWMC

Sampling and instrumentation

Soil (from removal of metal waste water line)

Wooden cable spools and wood from electrical substation
45

NE

NE

NE

NE

NE
41

38

192

192

48

WERF $^{b}$

WERF ${ }^{\mathrm{b}}$

Uncontaminated
RWMC

RWMC

WERF
Concrete: ${ }^{c}$

Incinerable

Compactible

Concrete: ${ }^{\mathrm{C}}$ 
Table 4. (continued).

\begin{tabular}{|c|c|c|c|}
\hline Components/systems/material removed & $\begin{array}{c}\text { Estimated } \\
\text { volume } \\
\left(\mathrm{ft}^{3}\right)\end{array}$ & $\begin{array}{c}\text { Actual } \\
\text { volume } \\
\left(\mathrm{ft}^{3}\right)\end{array}$ & Disposition \\
\hline \multicolumn{4}{|l|}{ Carbon steel: } \\
\hline Lube oil system & 83 & 83 & CFA landfill \\
\hline Heating system & 101 & 101 & CFA landfill \\
\hline Miscellaneous piping & 210 & $45 / 160$ & Salvage/CFA landfill \\
\hline Turbine-generator support structure & NE & $60 / 15$ & Salvage/CFA landfill \\
\hline Turbine building & 75 & 68 & Salvage \\
\hline Underground fuel oil tanks & 1,500 & 250 & CFA landfill \\
\hline $\begin{array}{l}\text { Miscellaneous metal equipment, } \\
\text { tanks, and materials }\end{array}$ & 450 & 391 & Salvage \\
\hline Asbestos insulation & 175 & 54 & CFA landfill \\
\hline Lead & 2 & 0.5 & Clean Lead Facility \\
\hline \multicolumn{4}{|l|}{ Miscellaneous: } \\
\hline Electrical/instrumentation & 250 & $30 / 145$ & Salvage/CFA landfill \\
\hline $\begin{array}{l}\text { Oil (from lube oil system and } \\
\text { generator circuit breakers) }\end{array}$ & NE & 17.2 & $\begin{array}{l}\text { Burned for energy } \\
\text { recovery }\end{array}$ \\
\hline Wood, metal, sweepings, trash, etc. & NE & 31 & CFA landfill \\
\hline \multicolumn{4}{|l|}{ Hazardous Waste } \\
\hline $\begin{array}{l}\text { Instruments containing mercury and } \\
\text { debris contaminated with mercury }\end{array}$ & NE & 3.3 & $\begin{array}{l}\text { Hazardous Waste } \\
\text { Storage Facility }\end{array}$ \\
\hline \multicolumn{4}{|l|}{ NE-Not estimated } \\
\hline \multicolumn{4}{|c|}{ a. Turbine-generator was originally estimated under uncontaminated waste. } \\
\hline \multicolumn{4}{|c|}{ b. Will be sent to WERF when operations resume. } \\
\hline \multicolumn{4}{|c|}{$\begin{array}{l}\text { c. Volumes for the turbine and reactor buildings contaminated and uncontaminated concrete were estimated } \\
\text { together. }\end{array}$} \\
\hline
\end{tabular}




\section{PERSONNEL EXPOSURE}

D\&D workers were required to wear thermoluminescent dosimeters (TLDs) to measure any radiation exposure received. Since the radiation/ contamination levels were so low and through application of as-low-as-reasonably-achievable (ALARA) principles, zero occupational radiation dose was recorded on the TLDs for the personnel that worked on this D\&D project. 


\section{POST-DECOMMISSIONING CONDITION}

The post-decommissioning physical condition of the turbine building site is shown in Figure 32. The area disturbed during the D\&D operations has been backfilled and graded to blend with the natural contours of the area. The area will be seeded with native grass and a permanent concrete marker, bearing an inscribed brass plate that identifies the site, will be placed at the approximate center of the former turbine building loca- tion upon completion of the BORAX-V Facility D\&D Project.

The radiological condition is contamination free as verified by the IVC verification statement.

A project data package containing all reports, contracts, work packages, procedures, and other pertinent project documentation and information will be assembled and stored at the Administrative Record and Document Control. 


\section{LESSONS LEARNED}

The following paragraphs define some of the lessons learned during this D\&D project:

- The NEPA documents, the radiological and the hazardous contaminant characterization of the facility, and Safety Analysis Reports all require early preparation and sufficient allowance for extended review requirements, so they can be in place for approval of the D\&D plan, the operational readiness review, and the start of cleanup activities.

- Cost escalation becomes a problem for D\&D projects spread over many years as updating and approvals of project documentation requires additional funding and more time. Project analysis showed that small jobs do not use craft people as efficiently as large jobs.

- Decommissioning time can be saved by removing radiologically clean components and structures in large pieces or sections. Recycling and reuse of these items reduces the amount of buried waste plus preserving resources. No significant new technology for D\&D activities were developed for future projects due to very low levels of radioactive contamination and absence of hazardous contaminants which allowed for the most part a routine hands-on D\&D operation.

- Reuse and recycling of uncontaminated components reduces the amount of buried waste and saves resources.

- Early interface with the IVC on D\&D projects is necessary to avoid problems that may result in duplication of work. Requirements of DOE Order 5400.5 (Reference 21) and the Verification and Certification Protocols for the Formerly Utilized Sites and Surplus Facilities Management Programs (Reference 22) should be included in the $D \& D$ Plan. Past D\&D Surveys of remediated areas should be well documented on drawings and maps that are to scale. Survey information should be recorded in disintegrations per minute (dpm) per surface area. Survey instruments should be agreed on by the IVC and Remedial Action Contracts (RAC) early in the program to avoid having to perform conversions for differences in type and size of instrument detectors. Establish schedule for IVC team to perform verification surveys on D\&D projects during time of year that inclement weather (cold) will not hamper operation of field instruments or expose IVC team to extremes. 


\section{REFERENCES}

1. Otto A. Schulze, BORAX-IV: Preliminary Report on the Present Series of Experiments with Oxide Fuels, TID-7535, Atomic Energy Commission, October 1957.

2. J. H. Handwerk and R. A. Noland, Oxide Fuel Elements for BORAX-IV, TID-7535, Atomic Energy Commission, October 1957.

3. D. L. Smith et al., BORAX-V Decontamination and Decommissioning Plan, PR-W-79-017, September 1979.

4. D. L. Smith, Decision Analysis for the Decommissioning of the BORAX-V Reactor Facility, PG-WM-84-003, August 1984.

5. D. L. Smith, Decontamination and Decommissioning Plan for the BORAX-V Facility, PR-W-79-017, Rev. 1, April 1985.

6. D. L. Smith, Decontamination and Decommissioning Plan for the BORAX-V Facility, PR-W-79-017, Rev. 2, November 1988.

7. J. H. Browder, Decision Analysis for the Decommissioning of the BORAX-V Reactor Facility, PG-WM-84-003, December 1988.

8. S. P. Fodgall and R. R. Rodriquez, Decontamination and Decommissioning Plan for the BORAX-V Facility, PR-W-79-017, Rev. 3, September 1990.

9. Department of Energy Idaho Field Office, INEL Low-Level Radioactive Waste Acceptance Criteria, DOE/ID-10112, Rev. 3, April 1987.

10. K. J. Durfee, EG\&G Idaho, Inc. letter to D. K. Thueson, EG\&G Idaho, Inc. "RML/Radiochemistry Analyses of BORAX Facility Smears and Air Samples," KJD-01-89, February 3, 1989.

11. Environmental Chemistry Sample Analyses Report Nos. 074, 100, 104, and 107, dated April 21, June 1 , June 6 , and June 15, 1989, respectively.

12. T. L. Rasmussen, EG\&G Idaho Inc., letter to J. E. Solecki, Department of Energy Idaho Field Office, "The Entombment of D\&D Facilities," TLR-74-89, May 22, 1989.

13. J. E. Solecki, Department of Energy Idaho Field Office, letter to T. L. Rassmussen, EG\&G Idaho Inc., "Entombment of D\&D Facilities," RFO-183-89, June 26, 1989.

14. "Environmental Checklist for BORAX-V Facility D\&D-Turbine Building," MISC 90-203, U.S. Department of Energy Idaho Field Office, April 3, 1990.

15. Department of Energy Idaho Field Office Memorandum-To-File for BORAX-V Facility "Decommissioning-Turbine Building, July 1990.

16. Department of Energy Idaho Field Office Memorandum-To-File for Generic Asbestos Removal Projects Performed by EG\&G Idaho, January 1989.

17. D. K. Halford, Oak Ridge National Laboratory, Grand Junction, Colorado, letter to T. A. Russel, DOE-HQ, "Verification Statement for BORAX-V Turbine Building at Idaho National Engineering Laboratory," January 17, 1992. 
18. EG\&G Idaho, Demolition Plan BORAX-V Turbine Building No. 718 Foundation Blasting. December 1991.

19. Department of Energy Idaho Field Office Memorandum-To-File for Tank Removal and Initial Site Assessment, MIS89-210, Rev. 1.

20. EG\&G Idaho, Inc., Development of Criteria for Release of Idaho National Engineering Laboratory Sites Following Decontamination and Decommissioning, EGG-2400, August 1986.

21. DOE Order 5400.5, "Radiation Protection of the Public and the Environment."

22. Department of Energy Idaho Field Office, Verification and Certification Protocol for the Office of Environmental Restoration Formerly Utilized Sites Remedial Action Program and Decontamination and Decommissioning Program, Rev. 3, November 1990. 


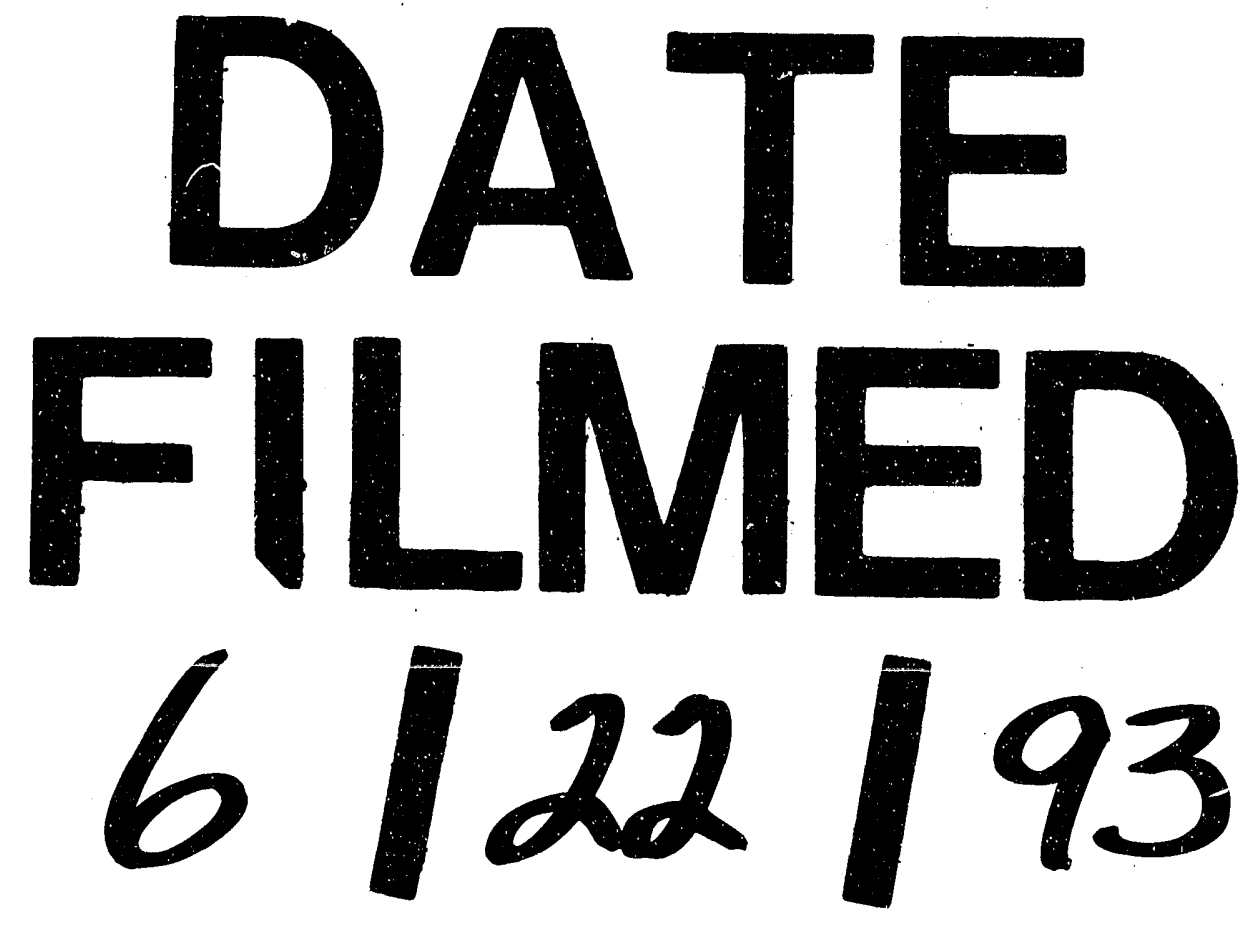

$\stackrel{2}{\bar{s}}$ 
